Article

\title{
Epistemic Communities, Human Rights, and the Global Diffusion of Legislation against the Organ Trade
}

\author{
Fikresus Amahazion
}

Department of Sociology and Social Work, National College of Arts and Social Sciences, Asmara 12423, Eritrea; Tel.: +291-711-8538; famahaz@emory.edu

Academic Editor: Martin J. Bull

Received: 11 August 2016; Accepted: 19 October 2016; Published: 27 October 2016

\begin{abstract}
Over the past several decades, over 100 countries have passed legislation banning commercial organ transplantation. What explains this rapid, global diffusion of laws? Based on qualitative data from in-depth interviews, historical analysis, and secondary sources, this paper explores the role played by the medical epistemic community and human rights in the global spread of laws against the organ trade. In addition to shaping, guiding, and influencing norms and approaches to transplantation, the epistemic community has been instrumental in the development of various resolutions, policy initiatives, recommended practices, statements, legislation, and model laws. Moreover, the epistemic community helped position the organ trade as an issue of societal and global importance, and it persistently encouraged states to undertake actions, such as implementing legislation, to combat the organ trade. Critically, the epistemic community's efforts against the organ trade incorporated the concepts of human rights, integrity, and dignity, which had diffused globally and become institutionalized in the period after WWII.
\end{abstract}

Keywords: world culture; human rights; organ trafficking; policy diffusion; epistemic communities; law; policy

\section{Introduction}

Transplantation, the process of replacing failing organs in one individual with healthy organs from another, is "hailed as one of the great miracles of modern science" ([1], p. 9) and celebrated as "one of the major accomplishments of the last half of the twentieth century" ([2], p. 20). Although saving or significantly extending innumerable lives worldwide [2], transplantation has also generated troubling consequences, including the global organ trade.

The organ trade, a "flourishing" multimillion-dollar, black market industry ([3], p. 222), has become a transnational issue, affecting all countries and regions. Central to the global growth and spread of transplantation and the organ trade-as well as initiatives to combat the latter-has been the global medical epistemic community, comprised of transplant doctors, surgeons, practitioners, and researchers. Effectively the most active global actor in promoting efforts against the organ trade, the epistemic community constitutes a network of various regional and transnational actors (individuals and organizations, such as the Transplantation Society (TTS), World Health Organization (WHO), and the International Society of Nephrology (ISN)).

Since arising in the 1950s and 1960s, the epistemic community has been key to many developments regarding transplantation, including recommended practices, guidelines, resolutions, declarations, legislation, and model laws. However, as an important transnational actor with broad global authority, the epistemic community has not been reviewed in detail. Accordingly, this paperpresents a history of 
the organ trade, and examines the rise, activities, and influence of the epistemic community in combating the organ trade.

Between January and December 2014, I conducted interviews with numerous individuals, including medical practitioners, researchers, policymakers, members of various organizations, journalists, rights activists, and lawyers. Interviews were open-ended and semi-structured [4], a particularly useful format since the study retained many exploratory features. Furthermore, open-ended questions offered subjects an opportunity to organize responses within their own framework, thus potentially increasing the validity of responses. While interviews and questions were semi-structured, they involved many follow-up queries and creative locutions in order to further probe issues of merit or pursue clarity [4].

In addition to interviews, I attended the World Transplant Congress (WTC) in July of 2014, allowing me to observe dynamics of the global transplantation community. The congresses are regular multidisciplinary gatherings that allow participants from around the world to "share information, learn from a variety of perspectives, present or critique research, raise questions, receive training, collaborate on topics of mutual concern, and coordinate potential responses to various issues" [5]. The congress, one of the largest, most comprehensive transplantation meetings ever assembled, focused on a variety of issues and involved representatives from over 80 countries [5,6]. During the WTC, I observed numerous presentations and panel discussions, attended a forum focusing on organ trafficking and harvesting, and conducted interviews with individuals from around the world.

Finally, I incorporate information gleaned from an assortment of sources, such as non-governmental organizations (NGOs), medical institutions, governmental or health ministries, and regional or global organizations (e.g., the United Nations (UN) or WHO). Documents examined include written laws, websites, newsletters, press releases or statements, government senate or commission hearings, summaries and reports, and countless news articles available from the Lexis-Nexis database or general online searches.

Data analysis is based on data triangulation: obtaining, comparing, and contrasting evidence from a wide range of data sources. Relying on multiple sources of data allows for the convergence of various lines of inquiry and strengthens validity $[7,8]$, and is important in revealing the role played by epistemic communities in combating the organ trade.

\subsection{The Organ Trade}

An underground, shadowy enterprise, the international organ trade is complex ([9], p. 55). Furthermore, it is largely misunderstood and can be permeated by extremism and sensationalism [10,11]. Though organ procurement and similar activities date back millennia [12], the contemporary organ trade arose within the context of globalization, through advances in medicine, technology, and the sciences, and a global shortage in organ donations and recipients' needs for life-saving transplantation [13-17]. ${ }^{1}$

Involving a range of health, criminal, and human rights issues, the organ trade affects all regions of the world [18]. Moreover, the organ trade is dynamic and fluid, frequently shifting to and appearing at different times and locations due to various factors. In the past, estimates have suggested that approximately five to ten percent of the total transplants performed worldwide involve trafficked organs, although obtaining accurate information or figures about the organ trade is recognized as difficult [19-21]. Regardless of location, the organ trade encompasses several different activities sharing the underlying trait of commercial organ transplantation or "a policy or practice in which an organ is treated as a commodity, including by being bought or sold or used for material gain" [22].

1 Recipients may often look to other sources, before their own family, friends, or relatives, for living donation (thus avoiding risks or pressure to family, friends, or relatives). 
One facet of the organ trade involves the trafficking of organs, tissues, and cells obtained through coercion, financial transaction, fraud, or consent [23]. ${ }^{2}$ Importantly, the notion of consent is often staunchly and widely rejected, since the organ trade occurs within the context of crippling inequalities, illiteracy, poverty, and vulnerability $[17,24-27] .{ }^{3}$ Decades of experience have illustrated that organ sellers "are the poor or the vulnerable, whose actions reflect financial desperation and ignorance, not autonomous agency" or willful consent ([28], p. 2).

In various poverty-ladenrural villages in Pakistan, large segments of the adult population have sold an organ, while in several countries many kidneys procured from the local population are for foreign recipients [18,29]. At times, vulnerable individuals may be "treated" for a medical ailment, which may or may not exist, and then have organs extracted without their knowledge or consent ([30], p. 672). Generally, organs sold for transplant generate considerable profits for traffickers, brokers, and corrupt officials, leaving meager (or no) returns for donors [31].

Another facet of the international organ trade involves the trafficking of humans for the end purpose of organ removal [31]. This facet of the organ trade received particular attention within the 2000 UN Trafficking Protocol, which states that trafficking is:

“...the recruitment, transportation, transfer, harbouring or receipt of persons, by means of the threat or use of force or other forms of coercion, of abduction, of fraud, of deception, of the abuse of power or of a position of vulnerability or the giving or receiving of payments or benefits to achieve the consent of a person having control over another person, for the purpose of exploitation. Exploitation shall include, at a minimum, the exploitation of the prostitution of others or other forms of sexual exploitation, forced labour or services, slavery or practices similar to slavery, servitude or the removal of organs" [32].

With the UN's 2000 Trafficking Protocol primarily focused on human trafficking for the purposes of general exploitation, analysts felt it failed to give adequate attention to the organ trade, lacked specifying important aspects of the phenomenon, and only included organ removal as an addendum or afterthought [33,34]. The medical community, which has long taken the lead on the issue of the global organ trade [35], especially thought a more conclusive, detailed description was required. In 2008, during an international conference in Istanbul, Turkey, a more thorough discussion of the organ trade was provided. The Declaration of Istanbul [22], released at the conclusion of the conference, defines organ trafficking as:

"the recruitment, transport, transfer, harboring, or receipt of living or deceased persons or their organs by means of the threat or use of force or other forms of coercion, of abduction, of fraud, of force or other forms of coercion, of abduction, of fraud, of deception, of the abuse of power or of a position of vulnerability, or of the giving to, or the receiving by, a third party of payments or benefits to achieve the transfer of control over the potential donor, for the purpose of exploitation by the removal of organs for transplantation" [22].

Part of the significance of the declaration is that it presents clear definitions of complex, potentially vague processes, thus creating a common framework for broader understanding and cooperation ([13], p. 116).Importantly, according to the UN, the previous lack of "internationally agreed definitions...to provide a framework for cooperation in combating the trafficking in human organs made it more

2 Budiani-Saberiand Karim (2009) define organ trafficking as "the unjust practice of using a vulnerable segment of a country or population (defined by social status, ethnicity, gender or age) as a source of organs" ([24], p. 48). While victims within the organ trade must not necessarily be from vulnerable populations, they overwhelmingly tend to be the poor, vulnerable, and marginalized within society $[20,24]$.

3 Consent is frequently paralleled with liberty—in terms of the freedom to sell organs—and may be put forward as an argument for permitting organ sales. At the same time, however, many observers and analysts conclude that since commercialism occurs within the context of crippling inequalities, illiteracy, poverty, and vulnerability, little freedom or liberty is actually expressed $[24,26,27]$. 
difficult to understand and analyse the problem and its extent, and eventually to take appropriate countermeasures at the national, regional and international levels" ([36], p. 1306).

Subsumed within the declaration's definitions is a description of transplant tourism, distinguished as, "[t]he most common way to trade organs across national borders" ([16], p. 956). Transplant tourism involves organ recipients traveling abroad to receive organs procured from donors, and it can include commercialism, organ trafficking, and human trafficking for organ removal [37]. Demonstrative of the complexity of the organ trade, transplant tourism can occur in several different ways.

One potential pathway involves recipients traveling to the donor's country of residence. Reports describe how recipients from across Southeast Asia have traveled to Taiwan and China to purchase organs procured from executed prisoners. Although Taiwan eventually ceased the practice after pressure from human rights organizations ([38], p. 58), China allegedly continues to take organs from executed prisoners $[18,27,39-41]$. This pathway is also illustrated by the "organ bazaars" of Turkey, Pakistan, and India, where foreigners arrive from far-flung locales to purchase organs from destitute locals [27].

A second pathway sees donors travel to the country of recipients. In some cases, donors from Eastern Europe or other developing nations have been brought to the USA, while Nepalese have been taken to India $[16,18]$. Notably, the recent discovery of a major transplant network between Israel and Costa Rica found that some Costa Rican donors were taken to Israel to provide organs [42].

The third type of transplant tourism occurs when both donors and recipients, as citizens of the same country, travel to another country for transplantation procedures. Often, this arrangement is made due to poor facilities and quality of care, high local costs, or stringent laws and regulations in the home country $[43,44] .^{4}$

In the final type of transplant tourism, recipients and donors, as citizens of separate countries, travel to a third country where transplantation is performed. This category has seen the growth of regional transplant hubs; for example, South Africa and Brazil have become favored centers for illicit transplantation activities, hosting donors from Eastern Europe and recipients from developed countries, such as Israel $[16,45] .^{5}$

Importantly, not all travel across national borders involving transplant recipients or donors is necessarily part of the illicit organ trade $[13,19]$. Rather, some travel for transplant involves the legal travel of related donor and recipient pairs from countries without transplant services to countries where transplantation is performed $[13,20]$. Also, transplant tourism is distinguished from general medical travel through the exploitation of donors who suffer coercion, threats, inducement, and fraud, and whose consent arises within the context of crippling poverty [24,37].

Beyond solely the purchase of organs, transplant tourism can affect other sectors of society. Global travel of potential recipients and donors may be arranged and facilitated by intermediaries and healthcare providers who coordinate travel and recruit donors. ${ }^{6}$ The Internet has also been used to attract foreign patients, with several websites offering all-inclusive transplant packages. Intriguingly, a pioneering survey of the global market revealed how the price of a renal transplant package can range between US\$70,000 to US\$160,000 [16], while the WHO estimates that brokers can charge as much as US $\$ 100,000$ to US $\$ 200,000$ for transplants [46]. ${ }^{7}$

Transplant tourism, through brokered, organized packages or individually arranged trips, sees recipients spend money on hotels, food, transportation, gifts or amenities, and excursions, providing a potentially lucrative source of income for developing economies $[37,47,48]$. For example, Canadians,

4 For example, in Kosovo, the lack of appropriate transplantation facilities led many Kosovars to purchase organs abroad [19].

5 Amongst the most infamous cases of this type of transplant tourism was the 2010 "Netcare" case in South Africa. Authorities discovered that 109 illegal kidney transplants had occurred between June 2001 and November 2003, in a scheme involving brokers, donors, and recipients from Israel, Romania, and Brazil [45].

6 Corruption (involving officials) can often be a key dimension within the process [39,40].

7 Since the organ trade is a black market activity, accurate figures are difficult to obtain, and estimates for these cost ranges can often vary considerably [11]. 
Britons, and Americans travel to countries such as India, Argentina, Cuba, and Chile [48,49]. Promising "first world health care at third world prices" [48], several Latin American, African, Southeast Asian, and Middle Eastern countries have become regional transplant tourism hubs.

Although accurate data remain elusive ([13], p. 117), meaning a fully comprehensive picture is still lacking, awareness of the organ trade's reach has undoubtedly grown [16]. For example, at the 68th session of the United Nations General Assembly (UNGA), Joy Ezeilo, Special Rapporteur on Trafficking in Persons, Especially Women and Children, revealed that the organ trade "is a real problem that occurs oftentimes" ([50], p. 2). Embodying the "dark side" of globalization, it has joined illicit drugs, humans, arms, diamonds, gold, and oil as an illegal multibillion-dollar industry. Recently, a report by Global Financial Integrity estimated that the organ trade generates annual profits between US $\$ 600$ million and US $\$ 1.2$ billion, with criminals capitalizing on globalization, new communication platforms, and improved transportation technologies [51-53].

The organ trade also represents a "health and human rights matter" [54-56]. Regarding health, findings suggest the organ trade leads to deterioration in health status for both recipients and donors [57]. Threats stem from unsafe and substandard practices and conditions ([58], p. 1183), as well as inadequate testing, screening, or postoperative care $[18,26,59,60]$. Along with maiming or death, hepatitis B, HIV, aspergillosis, diabetes mellitus, fungal sepsis, cytomegalovirus, tuberculosis, donor-transmitted malignancy, wound infections, fatigue, regret, depression, and stigma are potential complications [20,43,61]. These individual-level afflictions can expand into broader public health issues through the potential spread of diseases or micro-organisms, as well as the need for costly provisions of healthcare and various resources for donors who have sold organs or recipients returning ill from abroad $[57,62,63]$.

While commercial transplantation has occasionally been raised as a possible solution for organ donation shortages, it has more often been described as problematic, undermining altruistic donation, arousing serious ethical quandaries, involving or directly leading to profiteering, organized crime, and human trafficking, and categorized as a "gross violation of human rights" $[18,27,54,64]$. It violates internationally recognized rights such as rights to life, liberty, security, health and freedom from cruel or inhumane treatment, as well as various children's rights [37,55,65-67]. Amongst the clearest reflections of the organ trade's challenge to internationally recognized human rights is China's state-organized organ trade. Servicing recipients from all over the world and predicated on the forcible extraction of organs from executed prisoners, China's organ trade illustrates contempt and blatant disregard for basic rights and principles of human dignity [40,68].

While countries from all continents and regions are involved, implicated, or afflicted in some way by the organ trade $[18,27]$, the international response has been lackluster $[35,69,70] .{ }^{8}$ In 2009 , both the UN and the Council of Europe (CoE) called for a new, binding international treaty to prevent the harsh, criminal realities of the international organ trade [70,71], and the UN pronounced an urgent need for "...prohibition of financial gain from the human body or its parts as the basis of all legislation on organ transplants" [70]. These calls would only be heeded years later; in mid-2014, the CoE adopted the Convention against Trafficking in Human Organs [23], the world's first binding international agreement specifically focused on the organ trade.

Even with the decades-long absence of a binding international agreement, combating the organ trade has been a central feature within the world of transplantation, particularly due to the global medical epistemic community. The global medical epistemic community has broadened awareness of the organ trade, raised many concerns and outlined problematic implications, proposed solutions, and ultimately influenced transplantation policies and global positions.

8 Many states have implemented legislation and formulated mechanisms to combat the organ trade. However, quite problematically, many countries do not recognize some aspects of the organ trade-such as trafficking for the removal of organs-as "a form of exploitation" ([55], p. 908). 


\subsection{Epistemic Communities}

The concept of epistemic communities dates back to Ludwik Fleck and Michel Foucault, whose respective works discuss thought collectives and episteme [72-74]. For Fleck, thought communities involved groups exchanging ideas and interacting, while often remaining committed to a common set of ideas. Later, Kuhn explored the notion of a scientific community, noting that it involved individuals from a particular discipline whose work revolved around a shared paradigm [75]. Within sociology, Holzner (1968) was the first to use the term (in 1968), while Haas introduced the concept to international relations, seeking to understand the influence of scientists [76,77]. In the mid-1970s, Ruggie drew upon Foucault's early understanding of episteme, and broadened the scope of Kuhn's scientific community, arguing that epistemic communities arise from "bureaucratic position, technocratic training, similarities in scientific outlook and shared disciplinary paradigms" ([78], p. 570).

Though these respective contributions were important in formulating an early, foundational framework for understanding epistemic communities, the definitive discussion of epistemic communities would emerge in the early 1990s. Specifically, Peter Haas (1992) described epistemic communities as having:

"(1) a shared set of normative and principled beliefs, which provide a value-based rationale for the social action of community members; (2) shared causal beliefs, which are derived from their analysis of practices leading or contributing to a central set of problems in their domain and which then serve as the basis for elucidating the multiple linkages between possible policy actions and desired outcomes; (3) shared notions of validity-that is, intersubjective, internally defined criteria for weighing and validating knowledge in the domain of their expertise; and (4) a common policy enterprise-that is, a set of common practices associated with a set of problems to which their professional competence is directed, presumably out of the conviction that human welfare can be enhanced as a consequence" ([79], p. 3).

A global collection of specialists, experts, scientists and professionals, and representative "significant others" for states, organizations and individuals, epistemic communities are driving forces behind the elaboration of world cultural models and principles, such as rationality and rational progress [80]. Importantly, epistemic communities, through their professional expertise and technical knowledge, frame and articulate debate, while also helping address complex, interdependent, and difficult global issues and problems(since policymakers are often unfamiliar with the technical aspects of particular problems or issues) ([79], pp. 1-3). Furthermore, they help define state interests and legitimate goals of action [81], set global standards, participate in communication and socialization processes, promote new ideas and policy innovations, create international institutions, and diffuse a particular world vision based on rationality, order, and science $[82,83]$.

Epistemic communities' control and framing of ideas and knowledge can lead to new patterns of behavior. Diffusion occurs via epistemic communities' interactions within international organizations, in scientific bodies, at conferences, and through publications. These transnational links allow epistemic communities to exert concurrent pressure on governments and policymakers who redefine their own expectations, reach common understanding, and coordinate their behavior accordingly [82]. With world society lacking an overarching, authoritative state, there is room for innovation ([83], p. 169). In this context, the role and influence of epistemic communities gain credence, and they have become significant players in the international community $[79,84]$. Numerous analyses of epistemic communities have illustrated their influence in collective global responses to environmental pollution, whaling, arms control, global banking regulations, telecommunications, and international trade [82].

The following section reviews the history of the global organ trade in greater detail, while also noting the influence of the organ trade's epistemic community. The review suggests that the epistemic community arrived relatively recently, truly emerging only in the 1970s and early 1980s. The epistemic community raised and broadened awareness of the global organ trade, helped position and categorize 
the organ trade as a significant health, rights, and ethical issue, proposed solutions, and was influential to many international policy initiatives, resolutions, statements, and declarations.

\section{The Global Diffusion of Legislation against the Organ Trade}

\subsection{The Early Days}

The seeds of the organ trade movement were planted in the early 1950s as small, formal meetings of researchers and clinicians interested in the new subject of transplantation convened in 1952 in Harriman, NY. Averell Harriman, former US governor, diplomat, and presidential advisor, donated a conference center to Columbia University, and a handful of clinicians, doctors, and researchers presented papers on the rapidly evolving subject [85]. This first meeting was followed by several more held biennially, ultimately leading to the establishment of The Transplantation Society (TTS), a global organization that would quickly come to be regarded as "one of the healthiest and most productive international scientific societies in existence" ([86], p. 426). Eventually, the TTS developed into the global leader in transplantation, the guidance of ethical practice, and activities combating the organ trade $[25,54,87]$.

At the same time, in Europe, small national societies comprising scientists and clinicians and focusing on kidney diseases were emerging. These societies organized the first International Congress of Nephrology, held in France in September 1960, featuring approximately 100 participants and 75 papers covering a wide variety of topics [60,88]. The meeting provided the impetus for the eventual formation of the International Society of Nephrology (ISN) which, decades later, has grown into a prominent, active opponent of the organ trade, boasting a vast network of affiliated chapters and members from across the world [89].

Overall, at this stage, transplantation was in its infancy and conferences allowed specialists to share research, exchange ideas, broaden knowledge within the field, and cooperate to develop the still arcane subject. As activities continued, memberships steadily expanded, and medical practices improved, general excitement permeated the field.

Despite the excitement, the reality during the early period was that transplantation was not yet effective or safe. For example, by 1963, approximately two-thirds of all transplant recipients died from organ rejection ([90], p. xi). At a conference in the US in 1963, as many doctors lamented that the vast majority of their transplantation recipients continued to die, one report offered optimism. A young surgeon presented results showing high success rates, attributing them to a unique immunosuppressant that reversed organ rejection [85]. Word quickly spread and by 1967's International Congress of the Transplantation Society, held in Paris, hundreds of organs had been transplanted in chemically immunosuppressed recipients in the USA, Europe, and Australia.

Although broad success in general transplantation was still elusive, there was an emergent transplantation community. The ISN's 1966 meeting registered nearly 3000 participants from 54 countries [88], while the TTS's 1967 Paris conference saw 425 delegates attend, 200 of whom had become members of the increasingly influential TTS [85].

Generally, these early activities were pivotal to developing professional ties amongst participants that would strengthen over decades. Regarding commercialization, although there was "little to indicate" that there was "any trafficking or commerce in organs" ([91], p. 302), anti-commercialization activities were already surfacing. In 1967, Italy and Chile became the first countries to pass commercial transplantation legislation [92,93], while the first internationally framed anti-commercial article arose in 1970 under the guidance of the TTS. At a society meeting at The Hague, Netherlands, the TTS's Committee on Morals and Ethics released a brief statement asserting that, inter alia, "[ $t$ ]he sale of organs by donors living or dead is indefensible under any circumstances" ([94], p. 632).

The statement was somewhat of a landmark, but years would pass until further efforts were made or even required. Building upon the slow, yet tangible, progress of the 1960s, the 1970s witnessed greater societal entrenchment of transplantation [86], even though pessimism about survival rates 
was still apparent ([95], p. 192). New information and medical innovations were features of the increasingly globalized meetings. Patient mortality continued to improve, although only incrementally, and transplantation procedures were available in over 200 centers worldwide. On the legislative front, by the end of the 1970s, 14 countries had transplantation legislation in place.

\subsection{Progress, Emerging Problems, and an Initial Response}

Improvements in medicine and transplantation, and growth of the medical community bred optimism; the 1980 TTS global conference featured nearly 700 abstracts, and more than 1100 delegates from 37 countries [85]. Meanwhile, the ISN-which was less forthright in its anti-commercial stance than the TTS - held a 1981 congress with nearly 2700 delegates participating, and close to 1800 abstracts submitted [88].

Regarding medical practice, transplantation was rapidly becoming "accepted as a routine treatment" [25]; by now, over 50,000 total kidney transplants had been performed, and of the 6000 heart transplants performed worldwide by 1988, approximately 80 percent occurred between 1984 and 1988 [85,96]. These developments were augmented by the discovery of Cyclosporin A. The "wonder drug" considerably improved transplantation survival rates, and ushered in a new chapter in transplantation [41].

Cyclosporin A's discovery, and concurrent improvements in medical practices, meant transplantation was finally a viable, effective treatment for those suffering with end-stage organ failure. However, a small donor pool, and few voluntary post-mortem donations created a situation where demand for organs increased at a rate greatly exceeding supply. These factors and the conspicuous lack of comprehensive national or international laws or systems to address organ donation gave rise to the commercialization of transplantation and the lucrative international organ trade [92]. Throughout the early 1980s, newspapers in several countries regularly featured advertisements from desperate donors or recipients hoping to sell or buy organs, while in India transplant tourism began to blossom ([97], p. 762).

In 1983, hoping to capitalize on rising demand for organs, US physician H. Barry Jacobs attempted to establish the International Kidney Exchange. His proposal, which sought to broker organs from poor foreigners or impoverished Americans, was met with shock, dissent, and broad disapproval [27,98]. Objections were adamant the scheme would "exploit or injure desperate organ sellers" ([99], p. 179), and that it was "immoral and unethical" [100], while a former head of the American Association of Tissue Banks (AATB) derided the organ trade as "immensely damaging" [99,101].

Targeting Jacobs's proposal, future US Vice President and then Congressman Al Gore quickly introduced a national bill that would outlaw the organ trade. Subsequently, during US House of Representatives Hearings on transplantation in 1983, Dr. Robert Ettenger, president of the American Society of Transplant Physicians (ASTP), testified that the organ trade "is morally offensive and ethically offensive," and that the possibility for "...coercion of the poor...is heart-rending and frightening" ([102], p. 297). His testimony was supported by Dr. Edward N. Brandt, Jr., Assistant Secretary for Health at the US Department of Health and Human Services, who testified that the organ trade was an "immoral" activity, and that it "goes against the principles of medical ethics" ([102], p. 151). As well, Dr. Bernard Towers, who at the time was co-director and Professor of Anatomy, Pediatrics and Psychiatry at the UCLA Program in Medicine, Law and Human Values, argued that the organ trade would lead to a dramatic increase in "the chances of transmission of disease" ([102], p. 289). Dr. Towers further warned that the organ trade "would represent a major degradation for humankind," and that the organ trade should "constitute a Federal offense" ([102], p. 289).

Testimonies from others within the epistemic community raised concerns that were similar to those brought up by Ettenger, Brandt, and Towers. Ultimately, the widespread outrage and opposition against Dr. Jacobs's proposal would contribute to the enactment of the USA's 1984 National Organ Transplantation Act ([103], p. 339). Amongst other stipulations, the act made it "unlawful for any person 
to knowingly acquire, receive, or otherwise transfer any human organ for valuable consideration for use in...transplantation," and established criminal sanctions for violations [104].

Overall, the USA's 1984 legislation and its associated hearings underscored the importance of the epistemic community. With the organ trade characterized by mystery and great uncertainty, national policy makers turned to the epistemic community, delegating them with much responsibility. The epistemic community provided a wealth of "information and advice," while "illuminating the salient dimensions" of the organ trade, ultimately influencing the decisions and policies implemented by decision makers ([79], p. 4).

Globally, the nascent organ trade was yet to be fully grasped and, at times, reports were sensationalized or difficult to verify [105]. Various media accounts described a variety of kidnapping and organ trafficking scenarios [31]. In Latin America, rumors of the trafficking of children's organs, originating in colonial folklore, were especially abundant [106]. Honduran officials, Guatemalan authorities, and Nicaraguan sources even accused North Americans of engaging in the organ trade, while the USSR quickly disseminated the rumors internationally as part of its Cold War disinformation campaign $[107,108]$.

At about the same time, the medical community was becoming more aware of the issue, recognizing that the organ trade was flourishing and likely "increasing" [25,109]. In Egypt, disturbing reports about a thriving market in kidneys, involving medical misconduct and theft, began to circulate [110], while across the Middle East, surgeons in the Gulf States began to note the prevalence of the organ trade after seeing their patients travel to India to purchase organs from indigent sellers $[15,105]$. During a three-day, TTS-sponsored international symposium on transplantation held in Alberta, Canada in 1985, author and philosopher Malcolm Muggeridge used his keynote address to warn that the "hacking out of bits of people's organs and putting them on the market is becoming an extraordinarily lucrative occupation. It's going to be a very big trade" ([111], p. 314). Sir Peter Morris, TTS president in the mid-1980s, echoed Muggeridge's warnings by giving several speeches denouncing the fact that commercial transplantation was rearing its "ugly head" [85]. As rumors and reports persisted and dynamics of the organ trade remained ambiguous, angst and backlash surfaced, voluntary donations decreased further, and calls for greater understanding and a response began to rise $[85,92,107]$.

In 1985, the TTS built on its seminal 1970 statement, publishing a set of stringent guidelines for practice that emphatically condemned commercial transplantation [112,113]. The TTS stated that:

"[n]o transplant surgeon or team shall be involved directly or indirectly in the buying or selling of organs or tissues, or in any transplant activity aimed at commercial gain to himself or an associated hospital or institute. Violation of these guidelines by any member of the Transplantation Society may be cause for expulsion from the society" ([112], p. 715).

The TTS received support from the World Medical Association (WMA), which, in addition to condemning the organ trade, also called on governments of all countries to take active steps to prevent it $[92,113]$. With the international community's growing "concern" with the rise and "development" of the organ trade ([93], p. 396), more initiatives soon followed. May 1987 saw the World Health Assembly (WHA) pass Resolution 40.13; the resolution asserted that the organ trade "is inconsistent with the most basic human values and contravenes the Universal Declaration of Human Rights," and called for "study" and research in order to develop appropriate guiding principles for transplantation [114]. That same year, the World Medical Assembly presented The Declaration on Human Organ Transplantation [115], explicitly decrying “...the purchase and sale of human organs for transplantation" [115]. Notably, the World Medical Assembly's declaration also called on physicians to "protect the rights of both [donor and recipients]" [115]. ${ }^{9}$ Collectively, the various measures functioned

9 Specifically, the Declaration on Human Organ Transplantation notes that "A potential organ transplant offers no justification for a relaxation of the usual standard of medical care...[and that the] same standard of care should apply whether the patient 
to help frame transplantation and the organ trade as rights issues. Such a development was important, since representing an issue as a human rights problem can often help to "clarify" complex matters, attract broad attention, and encourage action [116,117].

Meanwhile, in the Arab world, host to many countries deeply involved within the organ trade, various initiatives were under way. In 1987, in Turkey, the Middle East Society for Organ Transplantation (MESOT) was established to "promote and encourage education, research, and cooperation in the field of organ transplantation...[and] create a scientific forum for discussion of all problems related to transplantation" ([118], p. 16). Composed of all the Arab countries, as well as Iran, Turkey, Pakistan, and the Central Asian countries, MESOT organized regular meetings, symposia, and annual congresses to improve transplantation practices in the region.

The year also saw the 12th session of the Council of Arab Ministers of Health draft A Unified Arab Draft Law on Human Organ Transplants. The document sought to prohibit the organ trade and noted "that no specialist, knowing an organ to have been acquired by such means, may use it in a transplant operation" [92,93]. Then in the following year, "the most detailed Fatwa [sic]on organ transplantation" was proclaimed during the Fourth International Conference of Islamic Jurists, held in February ([119], p. 821). Inter alia, the fatwa strongly "rejected any trading or trafficking of organs" ([119], p. 821).

With kidnapping and organ theft rumors swirling, in 1988 the European Parliament denounced alleged US involvement in the trade and adopted a motion "condemning the trade in organs of Third World babies" $[107,120]$. US officials vehemently denied the charges, criticizing them as sensationalist, disinformation, unverifiable, and supported by the USSR [108,121] —yet rumors would persist well into the 1990s.

In January 1989, in a case that made headlines throughout the UK, it was discovered that a British physician had been involved in selling kidneys from poor Turkish citizens. The scheme, based on fraudulent promises of employment, and involving exploitation and dishonesty ([122], p. 169), led to a national uproar. At a House of Commons committee that had convened to discuss the issue, then UK Health Minister Roger Freeman asserted, "the concept of organs being bought and sold for money is entirely unacceptable in a civilized society" ([123], p. 1). Rapidly responding to widespread alarm, "emotional outcry," societal "repugnance," and "public outrage" over the case, in July of 1989 the British Parliament enacted the Human Organ Transplant Act, banning the sale of human organs for transplant [122,124-126]. Effectively, the scandal and the subsequent law, which "for the first time, [imposed restrictions] on transplant activity," had "entrenched the view that commercialization of organ procurement was something...unsavoury and to be avoided" ([127], p. 129).

In 1989, the WHA would also issue Resolution 42.5, seeking to prevent the organ trade and calling for legislators to strengthen mechanisms to combat the organ trade $[128,129]$. Dr. Ursula Lehr, then West Germany's Health Minister, ardently supported the resolution, noting that "the idea of business-minded brokers taking advantage of the financial distress of people in the Third World, buying their organs for a pittance and reselling them to wealthy patients in developed countries, is awful for me" ([121], p. A6).

Overall, the 1980s saw the practice of transplantation "spread quickly," and by 1990, the practice was occurring in the Middle East, South America, and Africa-in addition to the wealthy, industrialized countries $[25,130]$. Though clear understanding of the organ trade was yet lacking, there was recognition that countries were struggling to "...generate enough organs to meet the demand" ([121], p. A6). The medical epistemic community was especially active in expanding discussion and disseminating analysis of transplantation and the organ trade, as specialists authored dozens of articles published in important journals, including The Lancet, Transplantation Proceedings,

is a potential donor or not." As well, it stipulates that donors and recipients (or their respective responsible relatives or legal representatives) have the right to "free informed consent" and that physicians must provide the "fullest possible discussion of the proposed procedure" [115]. 
and the Journal of Health, Politics, Policy and Law [27]. With general awareness and discussion of the organ trade growing, there was also a mounting impetus to act.

The emerging momentum and rising stature of the epistemic community and its efforts against the organ trade were paralleled by an incremental, yet steady, growth in tangible measures undertaken by states. The decade witnessed transplantation "become increasingly legislated and regulated, more formalized, and more organized" ([131], p. 837). For example, in 1970 there were two countries with commercial legislation, a figure slowly trickling to fourteen by 1980 . Yet, by the end of the 1980s—a decade of greater activity by the epistemic community - 46 countries had passed legislation. Importantly, this progress helped lay the foundation and create impetus for efforts against the organ trade to expand and become truly globalized in the 1990s and new millennium.

\subsection{A Spreading Issue and Broader Response}

In the 1990s, amidst continued technical and medical advances, sustained globalization, and rising levels of unemployment, corruption, and organized crime in the former USSR, the organ trade grew $[105,132,133]$. Early in the decade, the WHO observed that "the [organ trade] was reaching alarming proportions in the Third World, especially as advanced medical technology proliferates" [134], while Dr. Hugh Wood, then medical director of Singapore's National Kidney Foundation (SNKF), exclaimed "[the organ trade] is big business" ([135], p. 1). In Eastern Europe, as "[p]olitical and economic liberalization [and] internal and international militarism created new opportunity structures and daunting economic uncertainties," sex trafficking began to flourish, before shortly being joined by the trafficking of organs ([136], p. 119).

In response, and seeking to support implementation of World Health Assembly resolutions 40.13 (1987) and 42.5 (1989), the WHO convened a three-day international consultation in May 1990 [137]. Meetings involved presentations, updates, and reviews of progress or outstanding challenges within different countries or regions, and were an opportunity for "a broad group of international experts to convey their views, opinions, and insights" on responses to the organ trade ([137], p. 2). The multidisciplinary group also discussed the possible development of a future global document featuring guiding principles. Effectively, the meeting embodied how international conferences serve as venues for policy or knowledge development for epistemic communities [79,82]. Furthermore, though a variety of complex issues were raised, a broad consensus emerged on the need to completely eliminate the global organ trade and promote "greater cooperation" between countries ([137], p. 8).

Following the developments of its 1990 consultation, the WHO released the Guiding Principles on Human Organ Transplantation in 1991. Incorporating many of the considerations raised during the three-day 1990 consultation [137], the document reiterated the WHO's stance against the organ trade, and advised limiting organ procurement to voluntary, post-mortem donation or presumed consent systems [138]. Additionally, the WHO's guiding principles were again linked to the increasingly visible and influential concepts of human rights and dignity. For example, attached commentary for "guiding principle five" notes that the organ trade should be prohibited since it exploits vulnerable groups and conveys the idea that some persons lack human dignity. Furthermore, in promoting donation, states should always respect the intrinsic human dignity of donors [138].

Intriguingly, although the persistent kidnapping and "organ snatching" rumors still lacked substantiating evidence [139], they elicited varying responses on both sides of the Atlantic. In Guatemala, rumors-attributed to political agitators looking to unbalance the country's precarious socio-political position [140]—reached a tipping point in 1994 . With a lack of appropriate understanding and no coordinated state response, there was a series of attacks on foreigners [141]. By contrast, in Europe, the European Parliament passed the Resolution on Prohibiting Trade in Transplant Organs on September 14, 1993. The document stated:

“...whereas there is evidence that fetuses, children and adults in some developing countries have been mutilated and others murdered with the aim of obtaining transplant organs for export to rich countries, [and]...having regard to the current existence of trafficking in 
fetuses, children and incapable adults who are used as organ providers...[As well] action [is] to be taken to put a stop to the mutilation and murder of fetuses, children and adults in developing countries for the purpose of providing transplant organs" [139].

The resolution was partly influenced by the European "Report of the Committee on the Environment, Public Health and Consumer Protection on Prohibiting Trade in Transplant Organs" released months earlier. The report gave some credence to the rumors by paralleling doubts about the rumors to Holocaust denial [139]. Collectively, the European resolution and report offered some sensitive, nuanced, and informative discussion of the medical, ethical, and socioeconomic factors within the organ trade [139], helping to broaden understanding of the topic. Furthermore, the resolution promoted "European self-sufficiency of organs," thus targeting the important, yet frequently overlooked, "demand" side of transplant tourism ([142], p. 19).

In September 1994, The Resolution on Physicians' Conduct Concerning Human Organ Transplantation was adopted at the 46th WMA General Assembly. The resolution voiced "significant concern" about the continued reports of physicians engaged in the organ trade, and the exploitation of vulnerable populations, including children [143]. Three years later, the CoE drafted the Convention on Human Rights and Biomedicine, explicitly seeking to protect the rights and dignity of humans in the application of medicine [144]. Not only was the convention a milestone in international bioethics [145], ${ }^{10}$ it also directly applied to the organ trade. Article 19 stipulates that "transplantation...may be carried out solely for...therapeutic benefit," while Article 21 outlines that "[t]he human body and its parts shall not...give rise to financial gain" [144]. Through its underlying focus on rights, and its applicability to the organ trade, the convention helped affirm that the organ trade was an important human rights issue.

The year additionally saw the publication of the Bellagio Task Force Report on Securing Bodily Integrity for the Socially Disadvantaged in Transplant Surgery. The report was the culmination of a series of meetings convening in Bellagio, Italy. Attended by transplant surgeons, specialists, rights activists, and academicians, the meetings focused on a range of issues related to the organ trade. In addition to stipulating that the organ trade undermined the bodily integrity and human dignity of victims, the report asserted that there was a glaring need for an "organs watch" (i.e., an international committee) to investigate abuses by country and serve as a clearinghouse for information on transplantation practices [27]. Accordingly, in 1999, anthropologist Nancy Scheper-Hughes and several other researchers launched Organs Watch. The organization researches the global traffic in human organs, tracks the movements of people and organs around the globe, analyzes global inequities facilitating the organ trade, seeks to prevent rights abuses, and lobbies to change national and international laws governing the trade [146,147]. In tandem, the report and subsequent development of Organs Watch illustrate Haas's (1992) claim that "epistemic communities may contribute to the creation and maintenance of social institutions that guide international behavior" ([79], p. 4).

\subsection{Global Hotspots: China, Egypt, and India}

In the mid-1990s, a lurid, new dimension of the organ trade would be uncovered. Specifically, the Chinese government's use of organs procured from executed prisoners, which provided important "foreign dollars," elicited international attention [38,148,149]. While China's Ministry of Health had established the Human Organ Transplant Ordinance in 1995 to regulate the country's fledgling transplantation program and prohibit the organ trade ([150], p. 6), pervasive corruption and a lack of enforcement saw the organ trade-specifically the use of executed prisoners-continue unabated. The US State Department raised the issue in bilateral discussions with China in 1996, while Human Rights Watch (HRW) and the Laogai Research Foundation documented available statistics and reports from Chinese informants [27]. As well, members of the Bellagio Task Force, including David Rothman

10 Specifically, it was the first international treaty focused on bioethics and became one of the few measures protecting people potentially applicable to all countries of Europe [145]. 
and Tsuyoshi Awaya, visited China to investigate the allegations. Illustrating the rising prominence of the organ trade issue, Awaya later shared his findings at meetings with the US House Committee on International Relations in 1998 [27]. Nonetheless, the persistent and widespread international condemnations had little impact toward changing China's policies.

China's flagrant flouting of growing global norms and principles against the organ trade contrasted starkly with how Taiwan and India respectively responded to the organ trade. Taiwan, like China, had used executed prisoners as a source for organs throughout the late 1980s and early 1990s [39,151]. In 1991, 14 Taiwanese prisoners were executed, seeing a total of 37 organs removed and used for transplants ([152], p. 220). Such practices placed the country under great international pressure, particularly from human rights and medical organizations. For example, "in the early 1990s, the British Medical Association challenged surgeons in Taiwan about [the] practice" ([153], p. 54), while Amnesty International (AI) and various medical associations began to send letters to different branches of the Taiwanese government [154]. The pressure and notoriety would prove telling as Taiwan banned the practice in 1994 [38,151]. In response to Taiwan's policy change, many local Taiwanese "began to travel to [mainland China] to purchase organs there" [39].

Regarding India, during the 1980s and 1990s, it was shamefully derided as an "organs bazaar," since numerous foreigners flocked to the country in order to purchase organs from destitute locals ([97], p. 762). Annually, over 1000 kidneys were allegedly sold to wealthy foreign recipients ([155], p. 164). Media coverage condemned the practice, often shaming doctors and featuring vivid exposés, and pressure for a response grew [156]. During a 1989 global meeting on transplantation held in Ottawa, Canada, international surgeons in attendance claimed that, "in India, the commerce in organs seems to be getting out of hand and there is need for it to be regulated immediately" [156]. While a few Indian surgeons were opposed to prohibitions on the organ trade, many vociferously spoke out against the practice, referring to it as "immoral, ethically objectionable and socially degrading" [135].

Subsequently, in 1992, a bill banning the organ trade was proposed in the Indian Parliament, and the issue was referred to a select committee to investigate. Additionally, a series of conferences were conducted in multiple cities, raising awareness, sharing information, and promoting advocacy ([157], p. 591). After completing its investigation, the committee presented a detailed report that recommended banning the organ trade and the government finally took legislative action [156,158,159]. ${ }^{11}$ In June 1994, the Indian Parliament passed a bill banning the organ trade, and in the following month the Transplantation of Human Organs Act was officially enacted ([97], p. 762).

India's law represented an important progressive step, and "[resonated] well with...international efforts" and initiatives to combat the organ trade ([158], p. 113). Yet, it did not eliminate commercialism; while the "establishment of...[India's law] resulted in a shift of [many] transplant tourists from India to Pakistan" ([24], p. 50), the organ trade also continued to plague India itself [160,161]. In fact, sales allegedly continued "uninterrupted" ([162], p. 21), particularly to wealthy domestic and diaspora communities ([163], p. 11). In the years following enactment of the law, "there were [sic] a spate of reports in the print and electronic media about illegal...transplantation in India and the possible exploitation of economically weaker sections of the society" ([158], p. 111). Consequently, India later amended parts of its law, making "oversight and enforcement mechanisms more rigorous" ([28], p. 3).

Importantly, 1999 saw the beginning of research work conducted by the Coalition for Organ-Failure Solutions (COFS), an international health and human rights non-profit organization (featuring researchers and members of the medical community) that would be officially established in 2005. COFS's activities initially primarily focused on Egypt-a notorious hotbed for organ trafficking. Egypt had long lacked legislation governing transplantation or outlawing the organ trade, with the

11 With many other countries clamping down on the trade, India became an increasingly popular location for the organ trade, even being described as a "meat bazaar" [156]. 
latter "evolving into an organized business [beginning] in 1987" ([164], p. 1). The country soon became "the main locale for transplant tourism in the Middle East" ([165], p. 495); up to 90 percent of transplants in Egypt were commercial [54,166], and frequently involved "wealthy Persian Gulf Arabs" as recipients ([164], p. 1).

Throughout the 1980s and 1990s, vivid media reports exposed a thriving underground organ trade involving medical misconduct, organ theft, and exploitation [110]. The UN's Office for the Coordination of Humanitarian Affairs (UNOCHA) observed that "hundreds and possibly thousands of poor Egyptians are selling their organs, mainly kidneys and liver, each year to pay off their debts and buy food, making Egypt the center for the illicit organ trade" ([167], p. 8), while the WHO identified the country as one of five global organ trafficking "hot spots" [168]. As the issue festered, Dr. Hamdy Al-Sayed, head of Egypt's Doctors' Syndicate- the national authority that issues licenses for transplants in Egypt-lamented that "[i]t is very unfair that we have had no legislation regulating organ transplants so far. We are miles behind the world" ([166], p. 137).

Beyond the glaring absence of legislation, other important contributing factors to Egypt's organ trade were the country's socio-religious-influenced aversion to procuring organs from the dead, the large — and rising - prevalence of liver and kidney diseases, the increasing privatization of healthcare, the rapidly growing gap between rich and poor, the influx of poor, foreign migrants vulnerable to exploitation, and high levels of institutional and governmental corruption (with officials often profiting and thus allowing the activity to thrive) $[54,110,134]$.

Within this context, and in addition to its research work offering a greater understanding of local and regional dynamics of the organ trade, COFS provided awareness, outreach, advocacy, and victim support programs in Egypt-all of which had been "inadequate or wholly nonexistent" [54,169].

Over the years, COFS mobilized with local civil society organizations and NGOs, engaged with the highly influential religious community (the ulemma), and worked with policymakers in efforts to "establish or improve national legal frameworks on transplantation" [54,169]. As well, COFS developed a partnership with the WHO, which had become focused on engendering change in Egypt. The combination of internal efforts (such as those through COFS) and external pressures (via COFS's global links, the WHO, and the TTS) saw Egyptian policymakers and officials begin to recognize the grave implications of the organ trade. For example, Egypt's Minister of Health, Dr. Hatem El-Gabaly, would note that the organ trade "not only [violates] the principles of equity, justice and respect for human dignity, but [it] also [causes] a general sentiment of fear and distrust in the whole conduct of organ transplantation" [170]. In 2009, Dr. Mahmoud el-Meteini, head of one of Egypt's Liver Transplant Units, would solemnly declare, "things cannot continue like this" [168].

By 2010, Egypt finally implemented legislation which, according to Dr. Hussein Gezairy, the WHO's regional director for the Eastern Mediterranean, was "a significant step towards ending illegal organ trafficking" [171]. While the decisive factor in the law's enactment was the WHO-which had consistently offered "critical support" and exerted pressure-COFS's long-term advocacy and engagement work inside the country were also vital and not inconsequential [54]. Importantly, COFS served as a bridge-helping to introduce and diffuse global norms and approaches towards the organ trade into Egyptian society and transplantation. This encouraged an "expansion and shift in the national approach and perspective towards commercialism," helping to broaden discussions and frameworks of the organ trade to consider the organ trade's range of harmful implications and human rights dynamics [54]. COFS, along with the WHO and TTS, also reflect how organizations-despite lacking the power to enforce laws and having generally limited economic resources-can "lobby, criticize, and convince" states to act on global norms and principles [84]. Furthermore, as a collection of like-minded experts, doctors, and professionals, COFS, the WHO, and the TTS helped provide the Egyptian state with much-needed information and were able to influence (if not shape) the country's response and law [79,172].

Overall, the 1990s fed off momentum generated during the 1980s. The organ trade was capturing international attention and an array of organizations continued to actively seek ways to address 
the issue. Importantly, these developments were mirrored by state responses, and the decade witnessed 30 countries pass legislation. The organ trade, and efforts to stem it, it appeared, were truly becoming globalized.

\subsection{The New Millennium and Refocusing on China}

The new millennium, a period of much advocacy activity, mirrored past decades as the medical epistemic community remained central to the global community's awareness of and stance towards the organ trade. To begin, in 2000, the World Medical Association issued its Statement on Human Organ Donation and Transplantation, reaffirming the outright rejection of the organ trade and claiming commercialization "...can be coercive and should be prohibited" [173]. Additionally, the statement advised that states developing national strategies on transplantation should give due consideration to human rights [173].

In 2000, the organ trade issue was also included in two important international documents. Specifically, the world's first truly international human trafficking agreement, The Protocol to Prevent, Suppress and Punish Trafficking in Persons, especially Women and Children, was adopted-prohibiting the trafficking of people for exploitation, including for the "the removal of organs" [32]. Moreover, the United Nation's Optional Protocol on the Rights of the Child on the Sale of Children, Child Prostitution, and Child Pornography encouraged states to, inter alia, criminalize "the transfer of organs of the child for profit" [174]. That the organ trade was included in two highly publicized, much heralded global agreements - even somewhat indirectly_was an important progressive step and reflected the international community's ongoing recognition of and concern toward the organ trade.

In 2001, Dr. Wang Guoqi, a Chinese transplant doctor who had operated on "over 100 executed prisoners," added to Tsuyoshi Awaya's earlier analysis and further exposed the brutality of China's state-organized organ trade ([38], p. 114). Testifying at the American Congressional Committee on Human Rights, Dr. Wang expressed "deep regret and remorse," before vividly detailing how prisoners were executed so their organs could be sold to wealthy recipients ([38], p. 114). As "huge profits" rolled in, other military-run prisons and hospitals began "to design similar [execution and organ procurement] programs" ([38], p. 121). These revelations caused incredulity and reignited widespread global condemnation. The British Transplantation Society (BTS) unreservedly denounced the practice, describing it as "lamentable," and Dr. Stephen Wigmore, chairman of the BTS's ethics committee stated that the practice was "a breach of human rights and...unacceptable" [175]. The WHO, the World Medical Association, and the TTS-who had all unequivocally decried the practice on ethical and rights grounds-attempted to engage with Chinese doctors in order to end the practice $[149,176]$. After years of vehement denial, China eventually "acknowledged" the existence of the program, but firmly reiterated that prisoners were "willing donors" [40].

Subsequently, the WHO and TTS would work directly with China's Vice Minister of Health to support "positive developments" within Chinese transplantation while also "[maintaining] international pressure towards a change [in legislation]" ([149], p. 294). During the inaugural World Transplant Congress (held in Boston in July 2006), the TTS developed special guidelines for its interactions with China. The guidelines stressed that China's "policies were considered unacceptable," that doctors "transplanting organs and tissues from executed prisoners cannot become members of TTS," and that "scientific presentations [using] data or samples from recipients of organs from executed prisoners cannot be accepted for presentation at TTS meetings" ([149], p. 294).

At approximately the same time as the World Transplant Congress, a detailed report on organs harvesting in China garnered major international attention ([149], p. 294). David Matas, an international human rights lawyer and David Kilgour, a former member of parliament (MP) and a former secretary of state for the Asia Pacific region, investigated China's organ trade via interviews and examination of an array of secondary sources [149,177]. Amongst numerous charges, the report thoroughly detailed how organs were taken from unwilling prisoners, many of whom were Falun Gong practitioners. Though Chinese authorities denied the report outright, the TTS formally requested 
that the UN's Commission for Human Rights investigate the charges further [149]. To a certain extent, the report authored by Matas and Kilgour exemplifies how "information generated by an epistemic community may in fact create a [societal] shock," that can lead to pressure for action ([79], p. 14).

Eventually, in 2007, China passed the Human Transplantation Act banning the organ trade [20]. While it is difficult to estimate the exact influence exerted by the epistemic community-particularly the TTS - and the Matas and Kilgour report on the enactment of China's law, the legislation was widely heralded as an "important step forward" ([11], p. 197). ${ }^{12}$ In effect, however, the law was little more than a paper tiger, thus mirroring the country's 1995 ordinance. China continued to execute prisoners and procure organs at an unprecedented rate $[40,177,178]$, corruption (at the institutional and governmental level) remained pervasive, and the global transplantation community returned to a policy of cooperative engagement with Chinese officials.

In 2013, Dr. Francis Delmonico (then president of the TTS) and other TTS representatives collaborated with Chinese officials to develop the Hangzhou Resolution-a legal framework for donation and transplantation that also seeks to eliminate the organ trade $[177,179]$. The resolution expresses that China's "dependence upon organs from executed prisoners must be terminated," and that China "[affirms] its commitment to prohibit transplant tourism and to shut down organ trafficking and transplant commercialism" ([180], p. 123). Indicative of the global community's rapprochement policy toward China, Delmonico also used his presentation during the 2013 Chinese Transplant Congress to reiterate the TTS's desire for global cooperation and academic collaboration with Chinese professionals and transplant centers abiding by the Hangzhou Resolution [181].

Notably, the role played by the TTS in the development of China's 2007 legislation and 2013 resolution exemplifies how global civil society actors not only function as global "watchdogs," but can also shape, encourage, and strengthen states' enactment and implementation of policies and laws ([7], p. 189). Crucially, "these organizations usually have greater leeway than states to speak out and take action, and are, therefore, more able to push specific agendas" ([182], p. 5).

Yet, although China's 2007 legislation and 2013 resolution appear to indicate advancement, the country remains severely troubled by the organ trade, and it still "attracts transplant tourists...from [inter alia] the Gulf countries and Malaysia" ([165], p. 495). In 2013, amidst China's ongoing state-organized organ trade, Doctors Against Forced Organ Harvesting (DAFOH)-a collection of doctors and researchers committed to fighting the organ trade-initiated an international petition that would later be presented to the United Nations High Commissioner for Human Rights, Navi Pillay. The petition, registering over 1.5 million signatures over a period of only several months, called for an immediate end to forced organ harvesting from prisoners, particularly Falun Gong practitioners [177,183]. Subsequently, during an open forum held in San Francisco in July 2014, parallel although officially separate from the WTC 2014, DAFOH presented evidence and testimony from researchers, advocates, and former prisoners detailing the role of corruption, and the structure and extent of China's organ trade, which it describes as "a crime against humanity" [177,183]. Overall, DAFOH illustrates how epistemic communities can also function as sources of issue advocacy and promote a human rights agenda $[184,185]$.

\subsection{Sustaining International Attention}

In 2002, the CoE built upon its 1997 convention by drafting the Optional Protocol Concerning Transplantation of Organs and Tissues of Human Origin [186]. Not only does the protocol "[stipulate] a minimum international standard of protection [within]...transplantation," it also "constitutes an important transnational instrument for preventing the trade in organs" ([187], p. 131). For example, the protocol's recommendations advocate specific actions to eliminate commercial transplantation

12 Additionally, China's passing of the 2007 law may have been influenced by its hosting of the 2008 Olympics and the desire to avoid further international shame or a boycott. 
practices [186]. In the following year, the WHO conducted the first Global Consultation on Human Transplantation, an international meeting bringing together 37 clinicians, ethicists, social scientists, and government officials from 23 countries to discuss ethical, access, and safety issues in transplantation $[25,188]$. Held in Madrid, Spain, part of the framework for the meetings involved reaffirming existing principles surrounding transplantation and also proposing possible additions. Regarding the latter, discussions noted the need for protecting privacy, improving transparency, and refocusing on "vigilance and safety" [25]. These proposals would lead to 2004's WHA Resolution 57.18 , which not only urged member states to undertake measures to protect vulnerable groups but, recognizing the global complexity of the organ trade, also called for international cooperation and coordination to eradicate it [31,189].

Meanwhile, at the UN, the General Assembly (UNGA) issued a resolution on Preventing, Combatting, and Punishing Trafficking in Human Organs, calling on states to outlaw and combat the organ trade [190]. Further, it mandated the Secretary General to report on the extent of the organ trade and states' responses. Two years later, in 2006, the Secretary General presented an eagerly awaited report, the Commission on Crime Prevention and Criminal Justice on Preventing, Combating and Punishing Trafficking in Human Organs [191]. The report, based on a survey of 40 UN member states, noted a continued increase in the organ trade, a dramatic failure by states to prioritize it, and an urgent need for more understanding. Notably, the report also linked the organ trade to socioeconomic factors, such as unemployment, the lack of education, and poverty [31,191,192]. Collectively, the UN's resolution and report, combined with the global trafficking and children's rights agreements of 2000, served to broaden awareness of the organ trade, while again (re)affirming and "legitimizing" the organ trade as a global and rights issue.

With the organ trade increasingly recognized as global in nature, conversations and advocacy were also extending to more regions of the world. MESOT, founded in Turkey in 1987, remained a strong, active, thriving organization well into the new millennium; it organized regular congresses and meetings, and regional members engaged in various cooperative, productive initiatives. In Latin America, the Punta Cana Group, established in 2001, was active in seeking to improve the system of donation and procurement throughout the region. An important feature of the group's work involved training coordinators from across the region and promoting the elimination of commercial transplantation [193].

In 2004, the TTS also expanded its geographical regional affiliations to include six global regions [85], while the following year saw the WHO's Pan American Health Organization emphasize the importance of legal prohibitions against the organ trade and recommend physicians not perform transplants with commercially procured organs [15]. Afterward, in July 2007 and January 2008, an Asian Task Force on Organ Trafficking, composed of medical experts retaining ties forged during prior global meetings, convened in Taiwan. The Task Force examined the parameters of the problem within Asia, brainstormed possible solutions, and presented a series of recommendations-especially aimed at regional governments—-for prohibiting, preventing, and ending the organ trade in Asia [194]. In aggregate, the various international initiatives were illustrative of how efforts to combat the organ trade had assumed a globalized nature, and involved international coordination and cooperation.

In 2006, the inaugural World Transplant Congress was held in Boston, MA; described as the "largest international conference in the field of organ transplantation," the meeting featured over 6000 attendees and saw 4000 articles submitted [6]. The multidisciplinary gathering allowed participants-representing numerous countries and organizations- to "share information, learn from a variety of perspectives, present or critique research, raise questions, receive training, collaborate on topics of mutual concern, and coordinate potential responses to issues" [5]. Importantly, the broad success of the WTC would be an important factor in the establishment of a second global congress, occurring in San Francisco in 2014 [5].

An important development during the 2006 WTC was the revision of the TTS's membership statement, which underlined the importance that all donations and transplantations be performed 
within legal, ethical frameworks. As well, the meeting established an official collaboration between the TTS and the WHO; the two groups had traditionally focused on working with states to create legal frameworks complying with TTS ethical standards and WHO guiding principles.

\subsection{Important Developments}

While several guidelines, resolutions, and statements regarding the organ trade had previously been released by various organizations (e.g., UN, WHO, WMA, etc.), the epistemic community felt more was required to "put an end" to the "crime[s] against humanity and [the] abrogation of basic human rights" characterizing the organ trade ([195], p. 1089). A weakness of many existing agreements was that they did not specifically target the organ trade. For example, since the UN's Trafficking Protocol (2000) focused on human trafficking for the purposes of general exploitation, analysts felt it neglected to adequately address the organ trade, lacked specifying important aspects of the phenomenon, and only included "organ removal" in the definition as an addendum or afterthought [33,34].

As a result, members of the epistemic community proposed a guiding, regulatory framework for the global transplantation profession, modeled on the World Medical Association's highly successful Declaration of Helsinki $[25,29,196]$. Developed in June 1964, the Declaration of Helsinki is a statement of ethical principles that provides guidance to investigators and physicians involved in human research ([195], p. 1089), and it has become a central component of clinical research ([29], p. 358).

After a period of planning, discussions, and preparation, the Summit on Organ Trafficking and Transplant Tourism took place in 2008. Held in Istanbul, Turkey-as a symbolic coming together of "East and West" — the Summit led to the Declaration of Istanbul [25]. The TTS, a longtime opponent of the organ trade, was joined by the ISN in sponsoring the event, while participants included members of scientific and medical bodies, government officials, social scientists, and ethicists from around the world [22,25].

Crucially, the declaration became the first document to define transplant tourism, trafficking, and commercialism ([197], p. 722). With clear definitions of complex, potentially vague processes, the declaration thus helped create a common framework for broader understanding and cooperation ([13], p. 116), and it would receive over 100 endorsements from national and international professional organizations, and also government bodies [28]. Additionally, it was directly linked to globally resonant human rights principles, thus potentially helping to provide further legitimacy [198]. ${ }^{13}$ For example, its preamble notes that the declaration "builds on the principles of the Universal Declaration of Human Rights," while principle six of the Declaration notes that the organ trade violates principles of equity, justice and respect for human dignity [22].

Although non-binding, the Declaration draws authority from the degree to which it is codified in or influences national or regional legislation and regulations ([29], p. 358). Quite notably, then, its effect has been fairly pronounced since its release as several countries have strengthened existing or created new laws [51]. For example, in the lead up to the Istanbul Declaration [22], the Philippine government issued Administrative Order (AO) 2008-0004, strictly prohibiting transplant tourism ([201], p. 113), while after the adoption of the declaration, India amended parts of its Transplantation of Human Organs Act, making "oversight and enforcement mechanisms more rigorous" ([28], p. 3).

In Israel, "momentum in the buildup to and surrounding the Declaration was an important influence" in the implementation of the country's law banning the organ trade [202]. As well, the Declaration served to exert "...large external pressures..." and encourage "radical reforms"

13 For example, the global movement surrounding female genital mutilation/cutting (FGM/C) saw greater attention and legitimacy partly through the linking of the issue to the human rights framework ([199], p. 91). Specifically, the centuries-old practice of FGM/C had become the source of a broad international consensus and the target of unified international action after it was framed as a critical and fundamental human rights issue, whereas previously it was characterized as a feminist and medical issue [199]. Additionally, the success of the global campaign for women's rights as human rights illustrates the possibilities and effectiveness of the human rights discourse ([200], p. 100). 
in Japan [203], while Spain made special mention of the declaration when modifying its penal code in 2011 to stiffen sanctions for trafficking in organs or people for the purpose of organ removal ([28], p. 3). Last, the declaration and its "custodian group" were "instrumental" in Qatar's 2010 implementation of the Doha Donation Accord, which sought to meet local transplantation needs while discouraging citizens from travelling abroad for commercial transplantation [204,205].

In addition to influencing legislation, the declaration may have significantly decreased activities within the organ trade $[28,206]$. For example, following the establishment of Israel's law, arising in part through momentum related to the declaration, the number of Israelis travelling abroad to purchase organs "plummeted" [207,208], while in the Philippines, regulations and government initiatives combating the organ trade, arising out of cooperation between the Declaration of Istanbul Custodian Group (DICG) and local organizations, led to "a dramatic fall in transplant tourism" [29,209]. ${ }^{14}$ As well, the establishment of new regulations in Qatar, directly supported by the DICG, saw "the number of [Qatari] patients travelling abroad...[decrease] by about 90 percent" ([205], p. 15).

Overall, the declaration helped diffuse global norms about the organ trade, and served as a model or blueprint for how to appropriately implement rules, guidelines, and legislation regarding transplantation and commercialism ([83], p. 145). As well, the epistemic community served to "powerfully contribute to policy" ([211], p. 48), since beyond formulating the declaration, it provided advice and exhortation, and influenced states in terms of policy adoption and implementation.

Following the declaration, in 2009, the CoE and the UN conducted a joint study of the organ trade [71]. The report emphasized the need for solutions tailored to the various forms of the organ trade, since they involved different actors and dynamics. Acknowledging deficiencies within prior resolutions and conventions (e.g., the UN's 2000 Trafficking Protocol), it claimed that true solutions required stronger political will and cooperation, amongst other things (e.g., greater transparency).

2009 also saw the WHO add to its past contributions by publishing an extensive glossary on various aspects of the organ trade and transplantation. A response to the "lack of a globally recognized terminology and definitions on cell, tissue and organ donation and transplantation" ([212], p. 3), the glossary was instrumental in "[clarifying] communication in the [areas] of donation...[and] transplantation" ([212], p. 3). Furthermore, it helped provide a much-needed common framework for understanding the organ trade.

The year after the glossary's release, the 63rd session of the World Health Assembly (2010) called on states to formulate and enforce policies and legislation on the organ trade and to oppose commercial transplantation [213]. The call was issued shortly after Pakistan-one of the world's organ trafficking hotspots-finally banned the organ trade [59,161].

Pakistan's thriving organ trade, often referred to as an "organs bazaar" [214,215], was a direct outgrowth of high levels of corruption, as well as the country's long "lack of regulation [and] the presence of a large vulnerable rural population" ([216], p. 160). Countless reports and media articles documented how wealthy foreign recipients travelled to Pakistan to purchase organs from poor vendors, with 2000 to 4000 organs purchased annually and an annual turnover of approximately US\$20m [217,218]. The situation was further exacerbated in the early 1990s; after India passed a law banning the organ trade in 1994, many "transplant tourists" simply headed to neighboring Pakistan [24,161,218,219].

Although several bills banning the organ trade were proposed in Pakistan during the 1990s and early 2000s, the lack of political support and a strong opposition lobby meant proposed bills were never translated into law $[35,216]$. Within the opposition, a strong group of private medical institutions and physicians actively lobbied against the enactment of prohibition laws on the grounds that transplant tourism aided the economy [35]. Additionally, other advocates of commercialism

14 Significantly, in an exploration of recent changes in Israel and the Philippines in response to progressive legislation implemented under the influence of the Declaration of Istanbul, it was found that the number of individuals participating in the international organ trade and transplant tourism had dramatically reduced [210]. 
and transplant tourism petitioned the Federal Shariat Court on the grounds that prohibition against payment constituted a hurdle to saving human lives ([220], p. 647).

With Pakistan's absence of legislation eliciting global shame, a number of domestic organizations and professional bodies, including the Sindh Institute of Urology and Transplantation (SIUT), the Transplantation Society of Pakistan (TSP), the Pakistan Society of Nephrology (PSN), and the Pakistan Association of Urological Surgeons (PAUS), began to strongly advocate for a law denouncing the organ trade [216]. Their efforts would receive a strong injection of support in 2004 when the WHO offered its formidable backing. Specifically, the WHO provided extensive technical advisory support to the Ministry of Health towards implementing ethical regulations, and strongly suggested the country ban the organ trade [216].

Subsequently, the Ministry of Health and SIUT began drafting a proposed law, while physicians and civil society organizations produced and distributed information, mobilized supporters, conducted public seminars and conferences, enlisted backing from the media and religious leaders, and engaged with policymakers [59]. As well, the TTS, WHO, and SIUT collaborated on several highly publicized seminars and symposia to highlight the extent of the organ trade, delineate its consequences, and encourage the implementation of a law $[167,219]$. The broad campaign efforts were combined with the development of a strong alliance between the Ministry of Health and the Standing Committee for Health of the National Assembly, and together they decisively countered the opposition lobby [216].

Ultimately, the multifaceted campaign—involving physicians, various health organizations and professional bodies, the media, civil society, the Ministry of Health, and external support and pressure (involving the WHO and the TTS) - culminated in the promulgation of Pakistan's historical law in 2010 [216]. While the law's promulgation saw many of "...the once-thriving kidney bazaars in Pakistan closed" ([214], p. 636), enforcement and "implementation of the law [constitute] an uphill task" ([216], p. 165), and the organ trade continues to thrive in Pakistan [161].

Overall, the new millennium witnessed efforts against the organ trade consolidate past progress and expand to involve actors from around the world [169]. The organ trade was recognized as an international issue of utmost medical and human rights concern-receiving coverage in several prominent global agreements-and, notably, the global community was active within many of the organ trade's global "hotspots." Importantly, states continued to undertake legislative action (albeit in a slower fashion) and, by 2013, over 100 countries had passed legislation (see Figure 1 below).

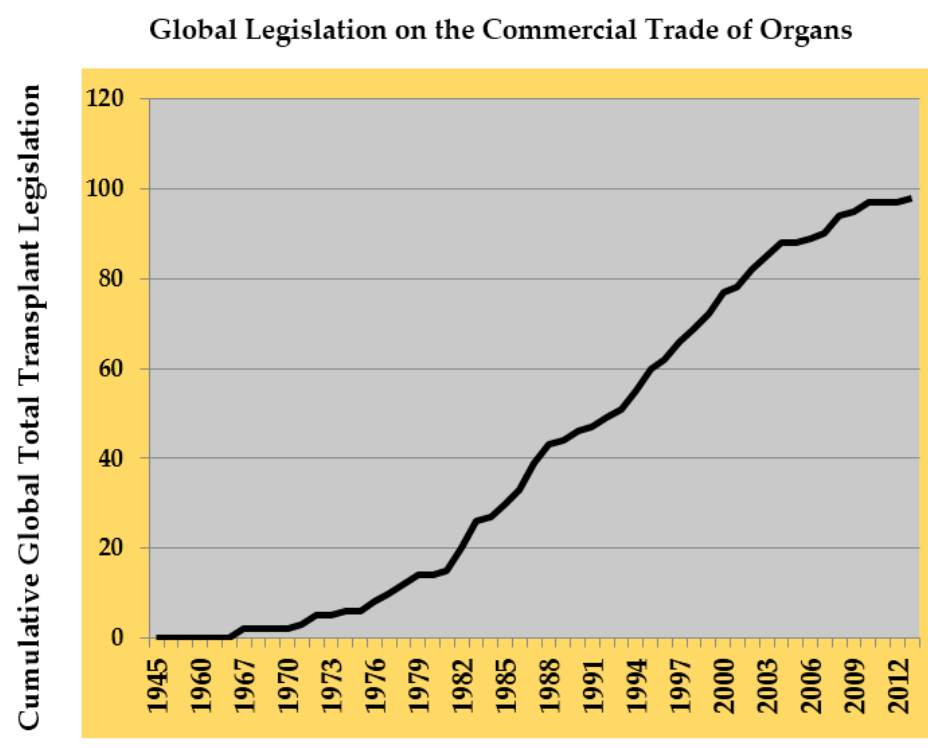

Figure 1. Illustrates the cumulative number of countries with legislation prohibiting the organ trade. Over several decades, legislation spread to many countries across the globe (modified from Amahazion 2016 [221]). 


\section{Conclusions}

Over the last several decades, transplantation "transformed from an experimental procedure performed in a handful of tertiary medical centers in highly developed western countries to a therapeutic intervention carried out in hospitals and clinics worldwide" ([151], p. 2739). As the practice spread in availability and developed into a viable option for end-stage organ failure, dramatic imbalances between organ supply and demand arose. Such an occurrence, combined with other processes, such as globalization, led to the organ trade, which expanded quickly to affect all regions and countries to some degree. With the international community failing to coordinate a response or organize initiatives to combat the issue, the global medical epistemic community performed an especially critical role. In addition to shaping, guiding, and influencing norms and approaches to transplantation, the epistemic community was instrumental in the development of various international policy initiatives, resolutions, and statements ([222], p. 103), and it helped position the organ trade as an issue of societal and global import. Furthermore, it doggedly encouraged states to undertake actions-particularly implement legislation-to combat the organ trade.

It is noteworthy that the epistemic community's efforts against the organ trade incorporated the concepts of human rights, integrity, and dignity, which had rapidly diffused globally and become institutionalized in the period after World War II [223,224]. Possessing great global authority and offering legitimacy, structuring the actions of states and individuals, and providing a common framework for global disputes, the principles were useful in the epistemic community's response to the organ trade by spreading awareness and helping frame the trade as a significant, problematic issue. Linking the organ trade to the global rights framework also helped to effectively "communicate [the] issue in a way that [engaged] the general public" [116,225].

Ultimately, with increasing global awareness of the organ trade's prevalence and negative social rights and health ramifications, and as the variegated efforts by the epistemic community persisted, states increasingly began to respond. Thus, the broad, rapid diffusion of policy arose within the context of the global growth of human rights, the construction, elaboration, diffusion, and institutionalization of world cultural models delegitimizing commercialism and the organ trade, and the persistent advocacy activities of NGOs and the medical epistemic community.

Acknowledgments: I thank Emory University, the Laney Graduate School, and the Department of Sociology for generous research and travel funding. I am especially indebted to John Boli, Frank Lechner, Edward Queen, and Richard Rubinson for their extensive support and feedback during the research process and in the drafting of this article. I also thank the many respondents and interviewees who were so generous with their time and feedback.

Conflicts of Interest: The author declares no conflict of interest.

\section{References}

1. Lesley A. Sharp. Strange Harvest: Organ Transplants, Denatured Bodies, and the Transformed Self. Berkeley: University of California Press, 2006.

2. Ronald Munson. Raising the Dead: Organ Transplants, Ethics, and Society. New York: Oxford University Press, 2002.

3. Alfred E. Eckes. The Contemporary Global Economy, Since 1980. Malden: John Wiley and Sons, 2011.

4. Dean Hammer, and Aaron Wildavsky. "The Open-Ended, Semi-Structured Interview: An (Almost) Operational Guide." In Craftways: On the Organization of Scholarly Work. Edison: Transaction Publishers, 1989.

5. Benedict Cosimi. "World Transplant Congress: Opening Ceremony." Paper presented at the World Transplant Congress, Moscone Convention Center, San Francisco, CA, USA, 27-30 July 2014.

6. The Transplantation Society. "Announcing the 2014 World Transplant Congress." Available online: http://www.tts.org/index.php?option=com_content\&view=article\&id=1178:announcing-the2014-world-transplant-congress\&catid=105:newsletter-2012-volume-9-issue-2\&Itemid=657 (accessed on 17 June 2014).

7. Franziska Bieri. From Blood Diamonds to the Kimberley Process: How NGOs Cleaned up the Global Diamond Industry. Burlington: Ashgate Publishing Limited, 2010. 
8. John W. Creswell, and Dana L. Miller. “Determining Validity in Qualitative Inquiry." Theory into Practice 39 (2000): 124-30. [CrossRef]

9. Sankar Sen, and Jayashree Ahuja. Trafficking in Women and Children: Myths and Realities. New Delhi: Concept Publishing Company, 2009.

10. Silke Meyer. “Trafficking in Human Organs in Europe: A Myth or an Actual Threat?" European Journal of Crime, Criminal Law and Criminal Justice 14 (2006): 208-29. [CrossRef]

11. Owen S. Surman, Reza Saidi, Ruth Purtilo, Mary Simmerling, Dicken Ko, and Thomas F. Burke. "The Market of Organs: A Window into A Poorly Understood Global Business." Transplantation Proceedings 40 (2008): 491-93. [CrossRef] [PubMed]

12. David Hamilton. A History of Organ Transplantation. Pittsburgh: University of Pittsburgh Press, 2012.

13. Francis Delmonico. "The Implications of Istanbul Declaration on Organ Trafficking and Transplant Tourism." Current Opinion in Organ Transplantation 14 (2009): 116-19. [CrossRef] [PubMed]

14. Arye Durst. "An Overview of Organ Transplantation." Jewish Medical Ethics 3 (1997): 7-11.

15. Ranee K. L. Panjabi. "The Sum of a Human's Parts: Global Organ Trafficking in the Twenty-First Century." Pace Environmental Law Review 28 (2010): 1-145.

16. Yosuke Shimazono. "The state of the international organ trade: A provisional picture based on integration of available information." Bulletin of the World Health Organization 85 (2007): 955-62. [CrossRef] [PubMed]

17. Jennifer M. Smith. "Dirty Pretty Things' and the Law: Curing the Organ Shortage and Health Care Crises in America." Chapman Law Review 12 (2009): 361-87.

18. Tazeen H. Jafar. "Organ Trafficking: Global Solutions for a Global Problem." American Journal of Kidney Diseases 54 (2009): 1145-57. [CrossRef] [PubMed]

19. Frederike Ambagtsheer. “Tackling Transplant Tourism: What Will Work?" Paper presented at the World Transplant Congress, Moscone Convention Center, San Francisco, CA, USA, 27-30 July 2014.

20. Debra A. Budiani-Saberi, and Francis Delmonico. "Organ Trafficking and Transplant Tourism: A Commentary on the Global Realities." Journal of Transplantation 8 (2008): 925-29. [CrossRef] [PubMed]

21. Ana Manzano, Mark Monaghan, Barbara Potrata, and Michelle Clayton. "The Invisible Issue of Organ Laundering." Transplantation 98 (2014): 1-4. [CrossRef] [PubMed]

22. The International Society of Nephrology, and the Transplantation Society. "Declaration of Istanbul on Organ Trafficking and Transplant Tourism—2014." Available online: http://www.declarationofistanbul.org/index. php?option=com_content\&view=article\&id=77\&Itemid=57 (accessed on 5 January 2015).

23. Council of Europe. "Convention against Trafficking in Human Organs." Adopted by the Committee of Ministers on 9 July 2014. Available online: https://www.coe.int/en/web/conventions/full-list/-/ conventions/treaty/216 (accessed on 14 August 2014).

24. Debra A. Budiani-Saberi, and Kabir Karim. "The Social Determinants of Organ Trafficking: A Reflection of Social Inequity." Social Medicine 4 (2009): 48-51.

25. Jeremy Chapman (The University of Sydney, Sydney, Australia). Personal communication, 2014.

26. Maqsood A. Noorani. "Commercial Transplantation in Pakistan and Its Effects on Western Countries." British Medical Journal (BMJ) 336 (2008): 1378-79. [CrossRef] [PubMed]

27. Nancy Scheper-Hughes. "The Global Traffic in Human Organs." Current Anthropology 41 (2000): 191-224. [CrossRef] [PubMed]

28. Gabriel Danovitch, Jeremy Chapman, Alexander Capron, Adeera Levin, Mario Abbud-Filho, Mustafa Al-Mousawi, William Bennett, Debra A. Budiani-Saberi, William Couser, Ian Dittmer, and et al. “Organ Trafficking and Transplant Tourism: The Role of Global Professional Ethical Standards—The 2008 Declaration of Istanbul." Transplantation 95 (2013): 1-7. [CrossRef] [PubMed]

29. Gabriel Danovitch, and Mustafa Al-Mousawi. “The Declaration of Istanbul—Early Impact and Future Potential." Nature Reviews Nephrology 8 (2012): 358-61. [CrossRef] [PubMed]

30. Lawrence Cohen. "Where It Hurts: Indian Materials for an Ethics of Organ Transplantation." Zygon: Journal of Religion and Science 38 (2003): 663-88. [CrossRef]

31. Emily Kelly. "International Organ Trafficking Crisis: Solutions Addressing the Heart of the Matter." Boston College Law Review 54 (2013): 1317-52. 
32. United Nations General Assembly. “United Nations Protocol to Prevent, Suppress and Punish Trafficking in Persons, Especially Women and Children, Supplementing the United Nations Convention against Transnational Organized Crime. General Assembly Resolution 55/25 of 15 November 2000." Available online: http://www.unodc.org/unodc/treaties/CTOC/ (accessed on 13 February 2014).

33. Anne Gallagher. The International Law of Human Trafficking. Cambridge: Cambridge University Press, 2011.

34. Gilbert Geis, and Gregory Brown. "The Transnational Traffic in Human Body Parts." Journal of Contemporary Criminal Justice 24 (2008): 212-24. [CrossRef]

35. Asif Efrat. "Combating the Kidney Commerce: Civil Society against Organ Trafficking in Pakistan and Israel." British Journal of Criminology 53 (2013): 764-83. [CrossRef]

36. The United Nations. Yearbook of the United Nations, 2006. New York: United Nations Publications, 2009, vol. 60 .

37. Alireza Bagheri. “Global Health Regulations Should Distinguish Between Medical Tourism and Transplant Tourism." Global Social Policy 10 (2010): 295-97. [CrossRef]

38. United States House of Representatives. “Organs for Sale: China's Growing Trade and Ultimate Violation of Prisoner's Rights. Hearing before the Subcommittee on International Operations and Human Rights of the Committee on International Relations. House of Representatives. One-Hundred Seventh Congress. First Session." 27 June 2001. Available online: http:/ / commdocs.house.gov/committees/intlrel/hfa73452.000/ hfa73452_0f.htm (accessed on 13 November 2014).

39. Theresa Chu (Falun Gong Human Rights Lawyers Group, Washington, DC, USA). Personal communication, 2014.

40. Ethan Gutmann. "Transplant Medicine at a Crossroads-A Call to Conscience." Paper presented at the Doctors against Forced Organ Harvesting Forum, San Francisco, CA, USA, 29 July 2014.

41. Trevor Harrison. "Globalization and the Trade in Human Body Parts." The Canadian Review of Sociology and Anthropology 36 (1999): 21-36. [CrossRef] [PubMed]

42. Kevin Sack. "Transplant Brokers in Israel Lure Desperate Kidney Patients to Costa Rica." The New York Times, 17 August 2014. Available online: http://www.nytimes.com/2014/08/17/world/middleeast/transplantbrokers-in-israel-lure-desperate-kidney-patients-to-costa-rica.html?smid=tw-share\&_r=0 (accessed on 21 November 2014).

43. Leslie Francis, and John Francis. "Stateless Crimes, Legitimacy, and International Criminal Law: The Case of Organ Trafficking." Criminal Law and Philosophy 4 (2010): 283-95. [CrossRef]

44. Jean McHale. "Organ Transplantation, the Criminal Law, and the Health Tourist." Cambridge Quarterly of Healthcare Ethics 22 (2013): 64-76. [CrossRef] [PubMed]

45. Jean Allain. "Trafficking of Persons for the Removal of Organs and the Admission of Guilt of a South African Hospital." Medical Law Review 19 (2011): 117-22. [CrossRef] [PubMed]

46. Clare Nullis-Kapp. "Organ Trafficking and Transplantation Pose New Challenges." Bulletin of the World Health Organization 82 (2004): 715-16.

47. Jonathan N. Goodrich. "Socialist Cuba: A Study of Health Tourism." Journal of Travel Research 32 (1993): 36-41. [CrossRef]

48. Leigh Turner. "'Medical Tourism' Initiatives Should Exclude Commercial Organ Transplantation." Journal of the Royal Society of Medicine 101 (2008): 391-94. [CrossRef] [PubMed]

49. Jason Behrmann, and Elise Smith. “Top 7 Issues in Medical Tourism: Challenges, Knowledge Gaps, and Future Directions for Research and Policy Development." Global Journal of Health Science 2 (2010): 80-87. [CrossRef]

50. Joy N. Ezeilo. "Statement of the Special Rapporteur on Trafficking in Persons, Especially Women and Children." Paper presented at the 68th Session of the General Assembly, Third Committee, Item 69(b), New York, NY, USA, 25 October 2013.

51. Frederike Ambagtsheer, and Willem Weimar. "A Criminological Perspective: Why Prohibition of Organ Trade Is Not Effective and How the Declaration of Istanbul Can Move Forward." American Journal of Transplantation 12 (2011): 571-75. [CrossRef] [PubMed]

52. Jeremy Haken. Transnational Crime in the Developing World. Washington: Global Financial Integrity, 2011.

53. Robert Thomas Naylor. Wages of Crime. Black Markets, Illegal Finance and the Underworld Economy. Ithaca: Cornell University Press, 2002. 
54. Debra A. Budiani-Saberi (Director, Coalition for Organ Failure Solutions, Bethesda, MD, USA). Personal communication, 2014.

55. Debra A. Budiani-Saberi, and Sean Columb. "A Human Rights Approach to Human Trafficking for Organ Removal." Medicine, Health Care and Philosophy 16 (2013): 897-914. [CrossRef] [PubMed]

56. Lucy Reynolds, and Martin McKee. “Organized Crime and the Efforts to Combat It: A Concern for Public Health." Globalization and Health 6 (2010): 1-13. [CrossRef] [PubMed]

57. Hasan Khamash, and Robert Gaston. "Transplant Tourism: A Modern Iteration of an Ancient Problem." Current Opinion in Organ Transplantation 13 (2000): 395-99. [CrossRef] [PubMed]

58. Kirpal Chugh, and Vivekanand Jha. "Commerce in Transplantation in Third World Countries." Perspectives in Clinical Nephrology 49 (1996): 1181-86. [CrossRef]

59. Asif Efrat. "The Rise and Decline of Israel's Participation in the Global Organ Trade: Causes and Lessons." Crime, Law, and Social Change 60 (2013): 80-105. [CrossRef]

60. Miran Epstein. "Sociological and Ethical Issues in Transplant Commercialism." Current Opinion in Organ Transplantation 14 (2009): 134-39. [CrossRef] [PubMed]

61. Ashley Anker, and Thomas Feeley. "Estimating the Risks of Acquiring a Kidney Abroad: A Meta-Analysis of Complications Following Participation in Transplant Tourism." Clinical Transplantation 26 (2012): $232-41$. [CrossRef] [PubMed]

62. John Gill. "Financial Consequences when the Transplant Tourist Comes Home." Paper presented at the World Transplant Congress, Moscone Convention Center, San Francisco, CA, USA, 27-30 July 2014.

63. Sheelagh McGuinness, and Jean McHale. "Transnational Crimes Related to Health: How Should the Law Respond to the Illicit Organ Tourism?" Legal Studies 34 (2014): 682-708. [CrossRef]

64. Monir Moniruzzaman. "Labyrinth of Violence in Organ Trafficking: Briefing of Dr. Monir Moniruzzaman." Speech presented before Tom Lantos Human Rights Commission, Michigan State University, MI, USA, 23 January 2012.

65. United Nations General Assembly. "Convention on the Rights of the Child." 20 November 1989. Available online: http:/ / www.un.org/documents/ga/res/44/a44r025.htm (accessed on 5 July 2014).

66. Sheri Glaser. "Formula to Stop the Illegal Organ Trade: Presumed Consent Laws and Mandatory Reporting Requirements for Doctors." Human Rights Brief 12 (2005): 20-22.

67. University of Minnesota Human Rights Library. "Universal Declaration of Human Rights: G.A.res 217A (III), UN Doc A/810 at 71." Available online: http://www1.umn.edu/humanrts/instree/b1udhr.html (accessed on 15 August 2014).

68. Jonathan Watts. “China Introduces New Rules to Deter Human Organ Trade.” The Lancet 369 (2007): 1917-18. [CrossRef]

69. United Nations Office on Drugs and Crime. “Trafficking for the Organ Trade." Available online: http: //www.ungift.org/knowledgehub/en/about/trafficking-for-organ-trade.html (accessed on 13 March 2015).

70. UN News Centre. "International Pact Needed to Prevent Organ Trafficking, UN-Backed Study Says." Available online: http:/ /www.un.org/apps/news/story.asp?NewsID=32521\&Cr=traffi\#.UhUJNOugdqZ (accessed on 23 January 2015).

71. Council of Europe and United Nations. "Trafficking in Organs, Tissues and Cells and Trafficking in Human Beings for the Purpose of the Removal of Organs." 2009. Available online: https:/ /www.edqm.eu/medias/ fichiers/Joint_Council_of_EuropeUnited_Nations_Study_on_tra1.pdf (accessed on 12 December 2014).

72. Mai'a D. Cross. "Rethinking Epistemic Communities Twenty Years Later." Review of International Studies 39 (2013): 137-60. [CrossRef]

73. Ludwick Fleck. Genesis and Development of a Scientific Fact. Chicago: University of Chicago Press, 1981.

74. Michel Foucault. The Order of Things. New York: Vintage Books, 1973.

75. Thomas Kuhn. The Structure of Scientific Revolution. Chicago: University of Chicago Press, 1962.

76. Burkart Holzner. Reality Construction in Society. Cambridge: Schenkman, 1972.

77. Ernst Haas, Mary Williams, and Don Babai. Scientists and World Order: The Uses of Technical Knowledge in International Organizations. Berkeley: University of California Press, 1977.

78. John Ruggie. "International Responses to Technology: Concepts and Trends." International Organization 29 (1975): 569-70. [CrossRef]

79. Peter Haas. "Introduction: Epistemic communities and international policy coordination." International Organization 46 (1992): 1-35. [CrossRef] 
80. Matthias Koenig, and Julian Dierkes. "Conflict in the World Polity-Neo-Institutional Perspectives." Acta Sociologica 54 (2011): 5-25. [CrossRef]

81. Gili S. Drori. Science in the Modern World Polity: Institutionalization and Globalization. Stanford: Stanford University Press, 2003.

82. Emanuel Adler, and Peter Haas. "Epistemic Communities, World Order, and the Creation of a Reflective Research Program." International Organization 46 (1992): 367-93. [CrossRef]

83. John W. Meyer, John Boli, George Thomas, and Francisco O. Ramirez. "World Society and the Nation-State." American Journal of Sociology 103 (1997): 144-81. [CrossRef]

84. John Boli, and George Thomas. "World Culture in the World Polity: A Century of International Non-Governmental Organization." American Sociological Review 62 (1997): 171-90. [CrossRef]

85. The Transplantation Society. "Four Decades of International Cooperation, Innovation, Growth and Progress: 1966-2006." 2006. Available online: http://www.tts.org/index.php?option=com_content\&view=article\&id= 6\&Itemid $=9$ (accessed on 29 November 2014).

86. Joseph Murray. "Organ Transplantation (Skin, Kidney, Heart) and the Plastic Surgeon." Plastic and Reconstructive Surgery 47 (1971): 425-32. [CrossRef] [PubMed]

87. The Transplantation Society. "About the TTS." Available online: https://www.tts.org/about-tts-5 (accessed on 24 September 2014).

88. Roscoe Robinson, and Gabriel Richet. "History of the ISN." Kidney International 59 (2001): 1-1000. [CrossRef]

89. International Society of Nephrology (ISN). "Advancing Nephrology around the World." Available online: http:/ / www.theisn.org/images/Membership/This_is_ISN.pdf (accessed on 25 August 2015).

90. David Petechuk. Organ Transplantation. Westport: Greenwood Publishing Group, Inc., 2006.

91. Abdallah S. Daar, Thomas Gutmann, and Walter Land. "Reimbursement, 'Rewarded Gifting', Financial Incentives and Commercialism in Living Organ Donation." In Procurement, Preservation and Allocation of Vascularized Organs. Edited by Geralyn M. Collins, Jean-Michel Dubernard, Walter Land and Guido G. Persijn. Berlin: Springer, 1997, pp. 301-16.

92. Sev Fluss. “Commerce in Human Organs: The International Response." World Health Forum 12 (1991): 307-22. [PubMed]

93. World Health Organization. "Human Organ Transplantation: A Report on Developments under the Auspices of WHO: 1987-1991." International Digest of Health Legislation 42 (1991): 389-413.

94. John Merrill. "Statement of the Committee on Morals and Ethics of the Transplantation Society." Annals of Internal Medicine 75 (1971): 631-33. [CrossRef] [PubMed]

95. Richard Rettig. "The Politics of Organ Transplantation: A Parable of Our Time." Journal of Health Politics, Policy and Law 14 (1989): 191-224. [CrossRef] [PubMed]

96. Clifford H. Patrick, Michael G. Phillips, and Arnold G. Diethelm. “Donor Nephrectomy.” In UNOS: Organ Procurement, Preservation and Distribution in Transplantation. Edited by Michael G. Phillips. Richmond: UNOS, 1991, pp. 53-66.

97. Kirpal Chugh. "Five Decades of Indian Nephrology: A Personal Journey." American Journal of Kidney Diseases 54 (2009): 753-63. [CrossRef] [PubMed]

98. Andrew Wancata. "No Value for a Pound of Flesh: Extending Marketinalienability of the Human Body." Journal of Law and Health 18 (2004): 199-228.

99. Jed A. Gross. "E. Pluribus UNOS: The National Organ Transplant Act and Its Postoperative Complications." Yale Journal of Health Policy, Law, and Ethics 8 (2008): 145-252. [PubMed]

100. Walter Sullivan. "Buying of Kidneys of Poor Attacked." The New York Times, 24 September 1983. Available online: http:/ /www.nytimes.com/1983/09/24/us/buying-of-kidneys-of-poor-attacked.html (accessed on 13 August 2014).

101. Margaret Engel. "VA Doctor Plans Company to Arrange Sale of Human Kidneys." The Washington Post, 19 September 1983, A9.

102. United States House of Representatives. "National Organ Transplant Act: Hearings before the Subcommittee on Health and the Environment of the Committee on Energy and Commerce, US House of Representatives, Ninety-eighth Congress, first session." 29 July, 17 and 31 October 1983. Available online: http://catalog. hathitrust.org/Record/002763479 (accessed on 1 February 2014).

103. Donald Joralemon. “Organ Wars: The Battle for Body Parts." Medical Anthropology Quarterly 9 (1995): 335-56. [CrossRef] [PubMed] 
104. United States Government Publishing Office. “National Organ Transplant Act: Public Law 98-507." United States Statutes at Large 98 (1984): 2339-48.

105. Nancy Scheper-Hughes. “Commodity Fetishism in Organs Trafficking." Body E Society 7 (2001): 31-61. [CrossRef]

106. Nancy Scheper-Hughes. “Theft of Life: Globalization of Organ Stealing Rumors." Anthropology Today 12 (1996): 3-11. [CrossRef]

107. Maria Morelli. “Organ Trafficking: Legislative Proposals to Protect Minors.” American University Law Review 10 (1995): 917-54.

108. Janice Raymond. “At Issue: Children for Organ Export?" Reproductive and Genetic Engineering 2 (1989): 237-45.

109. Walter Land. "The Problem of Living Organ Donation: Facts, Thoughts, and Reflections." Transplant International 2 (1989): 168-79. [CrossRef] [PubMed]

110. Sherine Hamdy. Our Bodies Belong to God: Organ Transplants, Islam, and the Struggle for Human Dignity in Egypt. Berkeley: University of California Press, 2012.

111. Clair Marcus. "Spectre of Commercialism Dominates Transplant Symposium." Canadian Medical Association Journal 133 (1985): 314-18. [PubMed]

112. The Transplantation Society. "Commercialization in Transplantation: The Problem and Some Guidelines for Practice." Lancet 2 (1985): 715-16.

113. World Medical Association. "World Medical Association: Statement on the Live Organ Trade." Paper presented at the 37th World Medical Association, Brussels, Belgium, October 1985. Available online: http:/ / www1.umn.edu/humanrts/instree/organtrade.html (accessed on 21 January 2015).

114. World Health Assembly. "Fortieth World Health Assembly-Resolution 40.13: Development of Guiding Principles for Human Organ Transplants." 4-15 May 1987. Available online: http://www.google. com/url?q=http:/ / www.who.int/transplantation/en/WHA40.13.pdf\&sa=U\&ved=0ahUKEwiNmrPRp_ DPAhVCtxoKHZ6kBr0QFggUMAA\&usg=AFQjCNF0sQ0WdgeG-o6AoZ3ZmDMVvLgv_A (accessed on 14 January 2015).

115. World Medical Association. "Declaration on Human Organ Transplantation." Paper presented at the 39th World Medical Assembly, Madrid, Spain, October 1987. Available online: http://www1.umn.edu/ humanrts/instree/organtransplantation.html (accessed on 6 February 2015).

116. Margaret Keck, and Kathryn Sikkink. Activists beyond Borders: Advocacy Networks in International Politics. Ithaca: Cornell University Press, 1998.

117. David Reubi. “Constructing Tobacco Control as a Human Rights Issue: Smoking, Lawyers and the Judicialization of the Right to Health." In Assembling Health Rights in Global Context: Genealogies and Anthropologies. Edited by Alex Mold and David Reubi. New York: Routledge, 2013.

118. Faissal Shaheen. "Organ Donation in the Middle East." Ethnicity and Disease 19 (2009): 16-17.

119. Mohammad Albar. "Organ Transplantation: A Sunni Perspective." Saudi Journal of Kidney Diseases and Transplantation 23 (2012): 817-22. [CrossRef] [PubMed]

120. Veronique Campion-Vincent. “Organ Theft Narratives." Western Folklore 56 (1997): 1-37. [CrossRef]

121. Maud Beelman. "Body Parts Needed for Transplants: Trade in Human Organs Stirs Global Attention." The Los Angeles Times, 16 July 1989, A6.

122. Sujit Choudhry, Abdallah S. Daar, Janet Radcliffe Richards, Ronald D. Guttmann, Raymond Hoffenberg, Margaret Lock, Robert A. Sells, and Nicholas L. Tilney. “Unrelated Living Organ Donation: ULTRA Needs to Go." Journal of Medical Ethics 29 (2003): 169-70. [CrossRef] [PubMed]

123. Robert Barr. "London Kidneys-for-Cash Scandal Prompts Action to Ban Sale of Organs." The Los Angeles Times, 16 July 1989. Available online: http:/ /articles.latimes.com/1989-07-16/news/mn-5772_1_organ-sales (accessed on 5 July 2015).

124. Ahad Ghods. "Ethical Issues and Living Unrelated Donor Kidney Transplantation." Iranian Journal of Kidney Diseases 3 (2009): 183-92. [PubMed]

125. Francoise Shenfield, and Stuart J. Steele. "Why Gamete Donors Should Not Be Paid: A Gift is a Gift, or Why Gamete Donors Should Not Be Paid." Human Reproduction 10 (1995): 253-55. [PubMed]

126. Terry Trucco. "Sales of Kidneys Prompt New Laws and Debate." The New York Times, 1 August 1989. 
127. Phil Dyer, and Sheelagh McGuinness. "The Allocation of Organs: The Need for Fairness and Transparency." In Organ Shortage: Ethics, Law and Pragmatism. Edited by Anne-Marie Farrell, David Price and Muireann Quigley. Cambridge: Cambridge University Press, 2011, pp. 122-36.

128. World Health Assembly. "Resolution 42.5: Preventing the Purchase and Sale of Human Organs." Paper presented at the Forty-Second World Health Assembly, Geneva, Switzerland, 8-19 May 1989.

129. Henryk Zielinski. Health and Humanitarian Concerns: Principles and Ethics: Guidelines for Red Cross/Red Crescent Health Professionals. Dordrecht: Martinus Nijhoff Publishers, 1994.

130. David J. Rothman. “The International Organ Traffic." The New York Review of Book 45 (1998): 1-2.

131. Sylvia B. Rodgers. “Legal Framework for Organ Donation and Transplantation." Nursing Clinics of North America Journal 24 (1989): 837-50. [CrossRef]

132. Dan Bilefsky. “Black Market for Body Parts Spreads Among the Poor in Europe." New York Times, 28 June 2012, pp. 1-3.

133. Frank Viviano. "New Face of Mafia in Sicily: Global Tentacles." The San Francisco Chronicle, 8 January 2001, A4.

134. Christopher Hedges. "Egypt's Desperate Trade: Body Parts for Sale." The New York Times, 23 September 1991, A1.

135. Charles P. Wallace. “Column One: For Sale: The Poor's Body Parts: Vast Market in Kidneys, Skin and Reportedly Even Eyes Stretches from the Mideast to Hong Kong. Slum Dwellers Line Up to Sell What They Can-For a Brief Break From Poverty." The Los Angeles Times, 27 August 1992. Available online: http:/ /articles.latimes.com/1992-08-27/news/mn-6885_1_kidney-sales (accessed on 24 June 2015).

136. Gail Kligman, and Stephanie Limoncelli. "Trafficking Women after Socialism: From, to, and through Eastern Europe." Social Politics: International Studies in Gender, State and Society 12 (2005): 118-40. [CrossRef]

137. World Health Organization. Informal Consultation on Organ Transplantation: Meeting Notes and Review. Geneva: World Health Organization-WHO Library, 1990.

138. World Health Organization. "Transplantation of Human Cells, Tissues, and Organs: WHO Guiding Principles on Transplantation." 1991. Available online: http://www.who.int/transplantation/en/ (accessed on 12 March 2015).

139. Todd Leventhal. "The Child Organ Trafficking Rumor: A Modern Urban Legend." A report submitted to the United Nations Special Rapporteur on the Sale of Children, Child Prostitution, And Child Pornography, the United States Information Agency, Washington, DC, USA, December 1994.

140. Anne Collinson. "The Littlest Immigrants: Cross-Border Adoption in the Americas, Policy, and Women's History." Journal of Women's History 19 (2007): 132-41. [CrossRef]

141. Abigail Adams. "Gringas, Ghouls and Guatemala: The 1994 Attacks on North American Women Accused of Body Organ Trafficking." Journal of Latin American Anthropology 4 (1998): 112-33. [CrossRef]

142. David Price, and Hans Akveld. "Living Donor Organ Transplantation in Europe: Re-Evaluating its Role." European Journal of Health Law 5 (1998): 19-44. [CrossRef] [PubMed]

143. World Medical Association. "World Medical Association: Resolution on Physicians' Conduct Concerning Human Organ Transplantation." Paper presented at the 46th WMA General Assembly, Stockholm, Sweden, September 1994. Available online: http://www1.umn.edu/humanrts/instree/physicianconduct.html (accessed on 26 June 2015).

144. Council of Europe. "Council of Europe. Convention for the Protection of Human Rights and Dignity of the Human Being with regard to the Application of Biology and Medicine: Convention on Human Rights and Biomedicine." 4 April 1997. Available online: http:/ / conventions.coe.int/Treaty/en/Treaties/Html/164.htm (accessed on 28 April 2015).

145. F. William Dommel, Jr., and Duane Alexander. "The Convention on Human Rights and Biomedicine of the Council of Europe." Kennedy Institute of Ethics Journal 7 (1997): 259-76. [CrossRef] [PubMed]

146. Patricia McBroom. "Program to Track Global Traffic in Organs." 10 November 1999. Available online: http:/ / www.berkeley.edu/news/berkeleyan/1999/1110/organs.html (accessed on 2 December 2013).

147. Organs Watch. “Organ Transplantation and Related Issues.” 1999. Available online: http://sunsite.berkeley. edu/biotech/organswatch/ (accessed on 4 February 2014).

148. Cesar Chelala. "China's Human-Organ Trade Highlighted by US Arrest of 'Salesman'." The Lancet 351 (1998): 735. [CrossRef]

149. Annika Tibell. “The Transplantation Society's Policy on Interactions with China." Transplantation 84 (2007): 292-94. [CrossRef] [PubMed] 
150. Alex He Jingwei, Allen L. Yu-Hung, and Leong Ching. "Living Organ Transplantation Policy Transition in Asia: Towards Adaptive Policy Changes." Global Health Governance 3 (2010): 1-14.

151. David J. Rothman, E. Rose, Tsuyoshi Awaya, B. Cohen, Abdallah S. Daar, Sergei L. Dzemeshkevich, C. J. Lee, R. Munro, H. Reyes, Sheila M. Rothman, and et al. “The Bellagio Task Force Report on Transplantation, Bodily Integrity, and the International Traffic in Organs." Transplantation Proceedings 29 (1997): 2739-45. [CrossRef]

152. Jerome Miller. Search and Destroy: African-American Males in the Criminal Justice System. New York: Cambridge University Press, 1996.

153. Veronica English, Gillian Romano-Critchley, Julian Sheather, and Ann Somerville. “Human Rights and Assisted Suicide." Journal of Medical Ethics 28 (2002): 53-54. [CrossRef] [PubMed]

154. International Amnesty. Further Information on Executions and Organ Transplantation. New York: Amnesty International, 1992.

155. George M. Abouna, M. M. Sabawi, S. A. Kumar, and M. Samhan. "The Negative Impact of Organ Donation." In Organ Replacement Therapy: Ethics, Justice, and Commerce. Edited by William Land and John Dossetor. Berlin: Springer, 1991, pp. 164-72.

156. Raj Chengappa. “The Organs Bazaar: Trade in Organs Taken from Live Donors Assumes Alarming Proportions in India." India Today, 31 July 1990. Available online: http://indiatoday.intoday.in/story/ trade-in-organs-taken-from-live-donors-assumes-alarming-proportions-in-india/1/315427.html (accessed on 24 January 2014).

157. Peter de Cruz. Comparative Healthcare Law. London: Cavendish Publishing Limited, 2001.

158. Sanjay Agarwal, Rakesh Srivastava, Sangeetha Gupta, and Shiv Tripathi. "Evolution of the Transplantation of Human Organ Act and Law in India." Transplantation 94 (2012): 110-13. [CrossRef] [PubMed]

159. Rahul Kakodkar, Arvinder Soin, and Samiran Nundy. "Liver Transplantation in India: Its Evolution, Problems and the Way Forward." The National Medical Journal of India 20 (2007): 53-56. [PubMed]

160. Debra A. Budiani-Saberi, Kallakurichi Rajendiran Raja, Katie C. Findley, Ponsian Kerketta, and Vijay Anand. "Human Trafficking for Organ Removal in India: A Victim-Centered, Evidence-Based Report." Transplantation 97 (2014): 380-84. [CrossRef] [PubMed]

161. Anwar Naqvi. "Addressing Limited Organ Donation Concerns in the Developing World: Pakistan." Paper presented at the World Transplant Congress, Moscone Convention Center, San Francisco, CA, USA, 27-30 July 2014.

162. K. P. Singh, and Chitrangada Singh. "Human Organ Transplant: Legal and Ethical Contours." The Indian Police Journal LV (2008): 1-85.

163. Lawrence Cohen. “The Other Kidney: Biopolitics beyond Recognition." In Commodifying Bodies. Edited by Nancy Scheper-Hughes and Loic Wacquant. London: SAGE Publications, Ltd., 2001, pp. 9-30.

164. Christopher Hedges. "Egyptian Doctors Limit Kidney Transplants.” The New York Times, 23 January 1992, p. 1.

165. Miran Epstein, and Gabriel Danovitch. “Organ Donation and Organ Trafficking: From Dangerous Anarchy to Problematic Equilibrium." Pediatrics and Child Health 23 (2013): 492-97. [CrossRef]

166. Debra A. Budiani. "Facilitating Organ Transplants in Egypt: An Analysis of Doctors' Discourse." Body and Society 13 (2007): 125-49. [CrossRef]

167. MESOT Newsletter. “The Middle East Society for Organ Transplantation.” 2010. Available online: http: //www.mesot-tx.org/home/MESOT_newslater2010.pdf (accessed on 16 December 2013).

168. Cam McGrath. “Egypt: Move to End Organ Trafficking." Inter Press Service: News Agency, 18 May 2009. Available online: http:/ / www.ipsnews.net/2009/05/egypt-move-to-end-organ-trafficking/ (accessed on 12 November 2013).

169. Debra A. Budiani-Saberi, and Amr Mostafa. "Care for Commercial Living Donors: The Experience of an NGO's Outreach in Egypt." Transplant International 24 (2010): 317-23. [CrossRef] [PubMed]

170. The Transplantation Society. "Statement of the Minister of Health of Egypt." Available online: http://www.tts.org/index.php?option=com_content\&view=article\&id=624:egypts-adoption-aimplementation-of-organ-transplantation\&Itemid=561 (accessed on 5 July 2014).

171. Al Arabiya News. "Egypt Organ Transplant Bill Welcomed by WHO." Available online: http://www. alarabiya.net/articles/2010/02/07/99626.html (accessed on 29 September 2014). 
172. Evan Schofer. "Science Association in the International Sphere 1875-1990: The Rationalization of Science and the Scientization of Society." In Constructing World Culture: International Non-Governmental Organizations since 1875. Edited by John Boli and George Thomas. Stanford: Stanford University Press, 1999.

173. World Medical Association. "WMA Statement on Human Organ Donation and Transplantation." Paper presented at the WMA General Assembly, Edinburgh, UK, October 2000. Available online: http:/ /www. wma.net/en/30publications/10policies/20archives/t7/ (accessed on 11 February 2015).

174. United Nations Human Rights Office of the High Commissioner. "Optional Protocol to the Convention on the Rights of the Child on the Sale of Children, Child Prostitution and Child Pornography." Available online: http://www.ohchr.org/EN/ProfessionalInterest/Pages/OPSCCRC.aspx (accessed on 25 December 2014).

175. Sarah Boseley. "UK transplant Patients go to China for Organs from Executed Prisoners." The Guardian News, 19 April 2006. Available online: http://www.theguardian.com/uk/2006/apr/20/health.china (accessed on 24 July 2015).

176. Vivienne Nathanson. "Opportunities to Offer Support to Members from the China Medical Association Have Been Limited." British Medical Journal 323 (2001): 1254. Available online: http://hdl.handle.net/10822/ 950393 (accessed on 24 October 2016).

177. Doctors against Forced Organ Harvesting (DAFOH). "Transplant Medicine at a Crossroads-A Call to Conscience." Paper presented at the Doctors against Forced Organ Harvesting Forum, San Francisco, CA, USA, 29 July 2014.

178. Sue Pondrom. "The AJT Report." American Journal of Transplantation 8 (2008): 3-4. [CrossRef]

179. Francis Delmonico, Jeremy Chapman, John Fung, Gabriel Danovitch, Adeera Levin, Alexander Capron, Ronald Busuttil, and Philip O'Connell. “Open Letter to Xi Jinping, President of the People's Republic of China: China's Fight against Corruption in Organ Transplantation.” Transplantation 97 (2014): 795-96. [CrossRef] [PubMed]

180. Jie-Fu Huang, Shu-Sen Zheng, Yong-Feng Liu, Hai-Bo Wang, Jeremy Chapman, Philip O'Connell, Michael Millis, John Fung, and Francis Delmonico. “China Organ Donation and Transplantation Update: The Hangzhou Resolution." Hepatobiliary and Pancreatic Diseases International 13 (2014): 123-26. [CrossRef]

181. Francis Delmonico. "The Transplantation Society Embraces the National Program for Deceased Organ Donation in China-OTC Hangzhou Resolution." Hepatobiliary Surgery and Nutrition 2 (2013): 317-18.

182. Lloyd Axworthy. "Introduction." In Human Security and the New Diplomacy: Protecting People, Promoting Peace. Edited by Robert McRae and Don Hubert. Montreal: McGill-Queen's University Press, 2001, pp. 1-13.

183. Adnan Sharif. "Transplant Medicine at a Crossroads-A Call to Conscience." Paper presented at the Doctors against Forced Organ Harvesting Forum, San Francisco, CA, USA, 29 July 2014.

184. Alison Brysk. Speaking Rights to Power: Constructing Political Will. New York: Oxford University Press, 2013.

185. Peter Haas. "Do Regimes Matter? Epistemic Communities and Mediterranean Pollution Control." International Organization 43 (1989): 377-403. [CrossRef]

186. Council of Europe. "Additional Protocol to the Convention on Human Rights and Biomedicine concerning Transplantation of Organs and Tissues of Human Origin." 24 January 2002. Available online: http:// conventions.coe.int/Treaty/en/Treaties/Html/186.htm (accessed on 12 March 2015).

187. Andrea Buchler, and Thomas Gachter. Medical Law in Switzerland. Frederick: Aspen Publishers, Inc., 2011.

188. World Health Organization. "Ethics, Access and Safety in Tissue and Organ Transplantation: Issues of Global Concern." Paper presented at the World Health Organization Meeting, Madrid, Spain, 6-9 October 2003.

189. World Health Assembly. "World Health Assembly Resolution 57.18: Resolution on Human Organ and Tissue Transplantation." Paper presented at the World Health Assembly, Geneva, Switzerland, 17-22 May 2004. Available online: http://www.who.int/transplantation/en/A57_R18-en.pdf (accessed on 14 February 2015).

190. United Nations. “United Nations ECOSOC Resolution 2004/22: Preventing, Combating and Punishing Trafficking in Human Organs." Paper presented at the 47th Plenary Meeting, New York, NY, USA, 21 July 2004.

191. United Nations Economic and Social Council. "Preventing, Combating and Punishing Trafficking in Human Organs." Report of the Secretary General, United Nations Economic and Social Council, Vienna, Austria, 24-28 April 2006. 
192. United Nations Global Initiative to Fight Human Trafficking. “The Vienna Forum to Fight Human Trafficking: 011 Workshop-Human Trafficking for the Removal of Organs and Body Parts." Background Paper, United Nations GIFT, Vienna, Austria, 13-15 February 2008. Available online: http:/ /www.unodc.org/documents/ human-trafficking/2008/BP011HumanTraffickingfortheRemovalofOrgans.pdf (accessed on 5 July 2015).

193. R. Mizraji, I. Alvarez, R. Palacios, C. Fajardo, C. Berrios, F. Morales, E. Luna, C. Milanes, M. Andrade, E. Duque, and et al. “Organ Donation in Latin America." Transplantation Proceedings 39 (2007): 333-35. [CrossRef] [PubMed]

194. Asian Task Force on Organ Trafficking. "Center for Ethics: Law and Society in Biomedicine and Technology-National Taiwan University." 2008. Available online: http:/ / www.jointcentreforbioethics.ca/ publications/documents / Asian\%20Task\%20Force\%20on\%20\%20organ\%20trafficking\%20.pdf (accessed on 23 May 2015).

195. Gabriel Danovitch. "From Helsinki to Istanbul: What Can the Transplant Community Learn from Experience in Clinical Research." Nephrology, Dialysis, Transplantation 23 (2008): 1089-92. [CrossRef] [PubMed]

196. Asif Efrat. "Professional Socialization and International Norms: Physicians against Organ Trafficking." European Journal of International Relations 21 (2015): 647-71. [CrossRef]

197. Peter Morris, and Stuart J. Knechtle. Kidney Transplantation: Principles and Practice, 7th ed. Philadelphia: Saunders Elsevier, 2014.

198. Ashley Baquero, and Josefina Alberu. "Ethical Challenges in Transplant Practice in Latin America: The Aguascalientes Document." Nefrologia 31 (2011): 275-85. [PubMed]

199. Elizabeth Boyle. Female Genital Cutting: Cultural Conflict in the Global Community. Baltimore: Johns Hopkins University Press, 2002.

200. Margaret Keck, and Kathryn Sikkink. "Transnational Advocacy Networks in International and Regional Politics." International Social Science Journal 51 (1999): 89-101. [CrossRef]

201. Gina Rocafort Gatarin. "Masculine Bodies in the Biocapitalist Era: Compromising Human Rights of Commercial Kidney Donors in the Philippines." Gender, Technology and Development 18 (2014): 107-29. [CrossRef]

202. Asif Efrat (The Interdisciplinary Center, Herzliya, Israel). Personal communication, 2014.

203. Misao Fujita, Brian T. Slingsby, and Akira Akabayashi. "Transplant Tourism from Japan." The American Journal of Bioethics 10 (2010): 24-26. [CrossRef] [PubMed]

204. Hanan Alkuwari, Riadh Fadhil, Yousef Almaslamani, Abdalla Alansari, Hassan Almalki, Hatem Khalaf, and Omar Ali. "The Doha Donation Accord Aligned with the Declaration of Istanbul: Implementations to Develop Deceased Organ Donation and Combat Commercialism." Transplantation 97 (2014): 1-2. [CrossRef] [PubMed]

205. Qatar Supreme Council of Health. "Putting Ethics into Practice." Magazine of the Supreme Council of Health 3 (2014): 10-15. Available online: https://www.moph.gov.qa/app/media/download/2332 (accessed on 21 January 2015).

206. Tracey Chan. "The Regulatory Challenges of International Transplant Medicine: Developments in Singapore." Medical Law International 10 (2013): 1-23. [CrossRef]

207. Asif Efrat. "Global Efforts against Human Trafficking: The Misguided Conflation of Sex, Labor, and Organ Trafficking." International Studies Perspectives 17 (2015): 34-54. [CrossRef]

208. Jacob Lavee, Tamar Ashkenazi, Avraham Stoler, Jonathan Cohen, and Rafael Beyar. "Preliminary Marked Increase in the National Organ Donation Rate in Israel Following Implementation of a New Organ Transplantation Law." American Journal of Transplantation 13 (2013): 780-86. [CrossRef] [PubMed]

209. Dominique Martin. "Comment faire face au traffic d'organes? Le point de vue du Declaration of Istanbul Custodian Group (How to Address Organ Trafficking-Point of View of the DICG)." Le Courrier de la Transplantation 2 (2014): 1-9. Available online: http://chirurgie.edimark.fr/publications/CTR/le-courrierde-la-transplantation\# (accessed on 3 April 2015).

210. Benita Padilla, Gabriel Danovitch, and Jacob Lavee. "Impact of Legal Measures to Prevent Transplant Tourism: The Inter-Related Experience of the Philippines and Israel." Medicine, Health Care and Philosophy 16 (2013): 915-19. [CrossRef] [PubMed]

211. Philip Jones. Education, Poverty and the World Bank. Rotterdam: Sense Publishers, 2006. 
212. World Health Organization. "Global Glossary of Terms and Definitions on Donation and Transplantation." 2009. Available online: http://www.who.int/transplantation/activities/ GlobalGlossaryonDonationTransplantation.pdf?ua=1 (accessed on 5 May 2015).

213. World Health Assembly. "Sixty-Third World Health Assembly: Resolutions and Decisions." Paper presented at the World Health Assembly, Geneva, Switzerland, 17-21 May 2010.

214. Naomi Pfeffer. "Eggs-Ploiting Women: A Critical Feminist Analysis of the Different Principles in Transplant and Fertility Tourism." Reproductive BioMedicine Online 23 (2011): 634-41. [CrossRef] [PubMed]

215. Mohammad Rai, and Orner Afzal. "Organs in the Bazaar: The End of the Beginning?" Politics and the Life Sciences 26 (2007): 10-11. [CrossRef] [PubMed]

216. K. M. Bile, J. A. R. H. Qureshi, S. Adibul Hasan Rizvi, Syed Anwar Naqvi, A. Q. Usmani, and K. A. Lashari. "Human Organ and Tissue Transplantation in Pakistan: When a Regulation Makes a Difference." Eastern Mediterranean Health Journal 16 (2010): 159-67.

217. Faheem Akhtar. "Organ Transplantation Law in Pakistan to Curb Kidney Trade: Chance for Global Reflection." Clinical Kidney Journal 1 (2008): 128-29. [CrossRef]

218. Syed Anwar Naqvi, Bux Ali, Farida Mazhar, Mirza Naqi Zafar, and Syed Adibul Hasan Rizvi. "A Socioeconomic Survey of Kidney Vendors in Pakistan." Transplantation International 20 (2007): 934-39. [CrossRef] [PubMed]

219. Syed Adibul Hasan Rizvi, Syed Anwar Naqvi, Mirza Naqi Zafar, Z. Hussain, A. Hashmi, Faheem Akhtar, M. Hussain, and E. Ahmed. “Pakistan Abolishes Kidney Market and Ushers in a New Era of Ethical Transplantation." International Journal of Organ Transplantation Medicine 1 (2010): 193-98. [PubMed]

220. Luc Noel, and Dominique Martin. "Progress towards National Self-Sufficiency in Organ Transplants." Bulletin of the World Health Organization 87 (2009): 647. [CrossRef] [PubMed]

221. Fikresus Amahazion. "Human Rights and World Culture: The Diffusion of Legislation against the Organ Trade." Sociological Spectrum 36 (2016): 158-82. [CrossRef]

222. Alison Brysk. Human Rights and Private Wrongs: Constructing Global Civil Society. New York: Routledge, 2005.

223. Michael Elliott. "Human Rights and the Triumph of the Individual in World Culture." Cultural Sociology 1 (2007): 343-63. [CrossRef]

224. Michael Ignatieff. Human Rights as Politics and Idolatry. Princeton: Princeton University Press, 2001.

225. Paul Gready. Fighting for Human Rights. London: Routledge, 2004.

(C) 2016 by the author; licensee MDPI, Basel, Switzerland. This article is an open access article distributed under the terms and conditions of the Creative Commons Attribution (CC-BY) license (http:/ / creativecommons.org/licenses/by/4.0/). 